\title{
Aristocrats, Mercenaries, Clergymen and Refugees: Deliberate and Forced Mobility of Armenians in the Early Medieval Mediterranean (6th to 11th Century A.D.)
}

\author{
Johannes Preiser-Kapeller
}

\section{Introduction}

Armenian mobility in the early Middle Ages has found some attention in the scholarly community. This is especially true for the migration of individuals and groups towards the Byzantine Empire. A considerable amount of this research has focused on the carriers and histories of individual aristocrats or noble families of Armenian origin. The obviously significant share of these in the Byzantine elite has even led to formulations such as Byzantium being a "Greco-Armenian Empire". ${ }^{1}$ While, as expected, evidence for the elite stratum is relatively dense, larger scale migration of members of the lower aristocracy ("azat", within the ranking system of Armenian nobility, see below) or nonaristocrats ("anazat") can also be traced with regard to the overall movement of groups within the entire Byzantine sphere. In contrast to the nobility, however, the life stories and strategies of individuals of these backgrounds very rarely can be reconstructed based on our evidence. In all cases, the actual significance of an "Armenian" identity for individuals and groups identified as "Armenian" by contemporary sources or modern day scholarship (on the basis of

1 Charanis, "Armenians in the Byzantine Empire", passim; Charanis, "Transfer of population"; Toumanoff, "Caucasia and Byzantium", pp. 131-133; Ditten, Ethnische Verschiebungen, pp. 124-127, 134-135; Haldon, "Late Roman Senatorial Elite", pp. 213-215; Whitby, "Recruitment", pp. 87-90, 99-101, 106-110; Isaac, "Army in the Late Roman East", pp. 132-135; Garsoïan, "Problem"; Brousselle, "L'integration des Arméniens", pp. 43-54; Redgate, Armenians, pp. 236-241; Settipani, Continuité des élites, passim; Dédéyan, Histoire, pp. 300-304, 311-317. Relatively reliable in this regard seems the calculation in Kazhdan/Ronchey, L'aristocrazia, pp. 333-338, according to which $5^{-7} \%$ of the "civilian" nobility and $25^{-26} \%$ of the "military" families in 11th-12th century Byzantium had a "Caucasian” (= Armenian or Georgian) background. 
onomastic material, for instance ${ }^{2}$ ) respectively the changeability of elements of identity (language, religious affiliation, naming practices) has found less attention in comparison with efforts to trace the "Armenian element" in Byzantium. Similar observations can be made with regard to scholarship on Armenian mobility into the spheres of the "Eastern" empire of Sasanian Persia and later the Arab Caliphate respectively the Islamic states; especially the change of the religious affiliation and the emergence of "Muslim Armenians" has caused some debate with regard to their qualification as "real" Armenians. For the Byzantine case, the magisterial article by Nina Garsoïan on "The Problem of Armenian integration into the Byzantine Empire" (1998) has not only summed up earlier research, but has also highlighted the complexities and dynamics of identity and of spatial as well as "cultural" mobility. ${ }^{3}$ Regarding the Islamic World the three volumes by Seta B. Dadoyan, who already had written an important study on Armenians in the Fatimid Empire, equally have produced new insights into similar phenomena. ${ }^{4}$

On this basis, also an attempt to adapt recent approaches from migration history on the early medieval mobility of Armenians is possible. Within the field, the "Armenian diaspora" of course has found attention, but this is especially true for its development since the early modern period; ${ }^{5}$ one has to mention here also the monograph by Sebouh Aslanian on the global trading diaspora of the Armenians of New Julfa in Persia in the 17 th century. ${ }^{6}$ Yet, as we will demonstrate in this paper, concepts developed by historians of migration in the last decades can be also be implemented effectively for earlier periods. Useful are of course also categories of a more traditional typology of migration such as duration, distance or scale (in terms of numbers of individuals) of mobility. However, in order to illustrate the actual complexity of mobilities and identity constructions as outlined by Garsoïan or Dadoyan, a "systems approach" towards migration phenomena seems promising. ${ }^{7}$ Therefore, we

2 Cf. also Settipani, Continuité des élites, pp. 488-491, on "typical" names of various families of the Armenian aristocracy.

3 Garsoïan, "Problem". Most recently, Kaldellis, Romanland, pp. 155-195, has (legitimately) discussed what he calls the "Armenian fallacy", that is the tendency in scholarship to identify individual member of the Byzantine elite as "Armenian" even several generations after the immigration of their ancestors and their integration into the Eastern Roman polity with regard to language, religion and identity. For a similar case regarding the Abbasid Caliphate see now Preiser-Kapeller, “Alī ibn Yahyā al-Arman̄̄".

4 Dadoyan, The Fatimid Armenians; Dadoyan, The Armenians, Vol. I and II.

5 Cf. for instance Hoerder, Cultures in Contact, pp. 174-177.

6 Aslanian, From the Indian Ocean to the Mediterranean.

7 Harzig/Hoerder, Migration History, pp. 78-114; Hoerder, Cultures in Contact, pp. 15-21; Hahn, Historische Migrationsforschung, pp. 21-36. 
survey material on the interplay between socio-economic, political and spatial structures both in the "society of departure"8 and in the "receiving societies", which very much defined the scope of action, and the actual agency of individuals and groups. Equally, we will try to identify networks established and/or used by individuals to effect mobility as well as integration within the social framework in the places of destination; yet, these networks could also work as constraining factors. ${ }^{10}$ The character of evidence from our period of course does not allow for a systematic quantitative survey on a large sample, but enables us to accumulate "micro-histories" of individuals and smaller groups across the centuries, which may provide inferences on general trends and mechanisms. ${ }^{11}$ In the following, we will (mostly based on Armenian, Greek and Latin sources) focus on Armenian migration towards the Byzantine Empire, while we have dealt with Armenian mobility towards the imperial spheres in the east (Sasanian Persia, the Caliphate) as well as with migration movements into early medieval Armenia in another study. ${ }^{12}$

\section{The Society of Departure: Early Medieval Armenia between Empires}

\subsection{Geopolitical and Socio-Political Parameters}

For migration as spatial phenomenon, geographical parameters of course very much matter. Since the ist century в.C., the Armenian highlands constituted the peripheries of competing empires and a centre of confrontations between them; this position also influenced attitudes of observers from imperial elites towards them. Already Tacitus called the Armenians "ambigua gens", ${ }^{13}$ situated between the Roman and Iranian great powers and sustaining political and cultural connections to both sides (see Map 12.1). This "ambiguity" became even stronger when the Armenians started to adopt Christianity since the beginning of the 4th century A.D. and (also in the eyes of the Iranian imperial centre) strengthened their ties to the new Christian Imperium Romanum of Constantine the Great and his successors. ${ }^{14}$ At the same time, the traditional

\footnotetext{
8 Harzig/Hoerder, Migration History, pp. 92-98.

9 Harzig/Hoerder, Migration History, pp. 102-110.

10 Harzig/Hoerder, Migration History, pp. 78-80.

11 Gylfi Magnússon/Szijárto, What is Microhistory.

12 Preiser-Kapeller, "Complex processes of migration". Cf. also now Preiser-Kapeller, “'Alī ibn Yahyā al-Armanī”.

13 Tacitus, Annales II 56, 1, ed. Koestermann.

14 Cf. Seibt, "Der historische Hintergrund".
} 
social structure with its powerful aristocratic houses, which was very similar to that of ancient Iran, ${ }^{15}$ remained strong. ${ }^{16}$ The struggle over Armenia at last lead to the partition of the country between Rome and the Sasanians in 387 A.D. (see Map 12.1) and the abolishment of the Armenian kingship over the next decades. In contrast to the European barbaricum, ${ }^{17}$ the invention of the Armenian alphabet at the beginning of the $5^{\text {th }}$ century initiated the emergence of a rich indigenous literature, which includes several important historiographical works. These texts provide us with a valuable view on three empires (RomeByzantium, Persia and, since the 7 th century, the Arab Caliphate) from the perspective of individuals which lived on the edge of these powers. As I was able to show in earlier studies, especially the image of the Byzantine empire in the Armenian historiography of the period moved between admiration of an Christian Empire, its power and civilisation, and - after the divergence of theological interpretations in the mainstreams of Byzantine and Armenian Christianity had become obvious since the late 6th century - contempt for an heretic power of oppression, often in coalition with other enemies of Armenia. ${ }^{18}$ In an often-quoted passage of the history attributed to Sebēos (7th century) we encounter a very grim interpretation of the policy of the neighbouring empires (and the mobility they forced upon the military of the country) vis-à-vis Armenia:

At that time [around the year 591] the king of the Greeks (t'agawor Yunac'), Maurice, ordered a letter of accusation (gir ambastanut'iwn) to be written to the Persian king [Xusrō II] concerning all the Armenian princes and their troops: "They are a perverse and disobedient race," he said: "they are between us and cause trouble. Now come, I shall gather mine and send them to Thrace; you gather yours and order them to be taken to the east. If they die, our enemies die; if they kill, they kill our enemies; but we shall live in peace. For if they remain in their own land, we shall have no rest." They both agreed. ${ }^{19}$

\footnotetext{
15 Rubin, "Nobility", esp. pp. 240-248.

16 Redgate, "Myth and Reality"; Garsoïan, Interregnum, esp. pp. viii-ix, also on the various "Armenias" existing in Late Antiquity; cf. also Garsoïan, "Armenia in the fourth century".

17 Halsall, Barbarian Migrations.

18 Preiser-Kapeller, "Between New Jerusalem". Cf. also Garsoïan, "Armenien”.

19 Sebēos 15, ed. Abgaryan, p. 86, transl. Thomson/Howard-Johnston, I, p. 31. Garsoïan, "Marzpanate", p. 109; Preiser-Kapeller, "Kaysr", pp. 190-191; Thomson, "Armenia", p. 169; Dölger, Regesten, nr. 108*; Garsoïan, Interregnum, pp. 4-5.
} 
At the same time, Armenian historians were very well aware that especially the internal framework of political power allowed Byzantium, Persia or the Caliphate to exert their influence within the country or even to divide it into spheres of interest. Neither during the time of monarchic rule before 390/428 and after 884/885 (when the noble houses of Bagratuni and of Arcruni succeeded in the restoration of - again competing - monarchies ${ }^{20}$ ) nor during the period of direct imperial suzerainty over Armenia's nobility, the fragmentation of the country's political structures (again also promoted by the geographical fragmentation of the Armenian highlands) allowed for the formation of a regional power centre which could compete with the empires on its borders. ${ }^{21}$

Armenian society, as far as we are able to reconstruct especially based on the indigenous texts, was divided along the line "noble" (azat) - "not noble" (anazat; including artisans, peasants and merchants). The nobility was dominated by several dozens of houses (tun) of magnates (the naxarark'), who based their power on their hereditary landed property worked by anazat, the number of their armed retainers from the lower aristocracy and their hereditary offices and positions of honours, which followed an elaborate ranking system, at the royal court. ${ }^{22}$ Within this framework, sources describe a constant struggle among the great houses for power and prestige, already in the period of Arsacid monarchy and even more afterwards. And already before the end of the kingdom (in 428 A.D.), the material and symbolic distinctions bestowed by superior external imperial powers (such as the emperor or the Great King) could become essential for the manifestation of rank and power within the Armenian aristocracy, even more so afterwards. Therefore, exterior powers usually would find a faction within the nobility prepared, at least for some time, to support their efforts for control over the Armenian highlands. ${ }^{23} \mathrm{~A}$ description of the ideal state of miabanut iwn (unity, concord) among the aristocracy is given in the history of T'ovma Arcruni (1oth century), together with the insinuation of the decline of this unity and its consequences:

For the Armenian princes with their hosts of knights and troops were still living in unison and harmony and concord, though in secret they had suspicions of treachery. However, when discord began to insinuate itself within that unity, they grace of the divine power departed and withdrew.

\footnotetext{
20 Garsoïan, "Independent Kingdoms".

21 Preiser-Kapeller, "Kaysr", pp. 200-201.

22 Cf. esp. Adontz/Garsoïan, Armenia; Redgate, Armenians; Garsoïan, "The Aršakuni Dynasty".

23 Adontz/Garsoïan, Armenia; Garsoïan, "Marzpanate".
} 
Concerted plans were disregarded in combat and in other matters affecting the administration of the country. (...) They sent letters and messengers to the Caliph secretly from each other. ${ }^{24}$

Discord (or anmiabanutiwn) is a far more prominent motif in Armenian historiography; ${ }^{25}$ it is the main reason of the failure of common actions against imperial powers. ${ }^{26}$ It also describes the state that prevailed in Armenia on the eve of the first Arab invasion. ${ }^{27}$ Yet anmiabanut iwn did not only restrict the chances of collective action of the Armenian aristocracy, but also the stability of foreign domination; just as the Armenian kings, also the representatives installed by the imperial overlords were not able to enforce universal allegiance to the suzerain. Therefore, the structure of the Armenian society also allowed for a certain degree of flexibility in relations with the great powers. As Nina Garsoïan has stated: “...the strength and permanence of the tun forged a social structure capable of surviving even in moments of political eclipse and the decentralized character of the society diminished its chances of total annexation." ${ }^{28}$ This "decentralized character" permitted the adaptation to the separation between various rulers and spheres of interest of the neighbouring empires and the existence of multiple layers of authority and loyalty. ${ }^{29}$ Thus, one member of the Mamikonean clan (the most prominent tun in this period) could lead a rebellion in Persian Armenia in 450/451, whereas a relative served as imperial general in Roman Armenia; forming "trans-local families" therefore could be one strategy for noble houses to maintain power. ${ }^{30}$ Individual noblemen and clans could gain a variety of options, and even the aristocracy at large could achieve a certain degree of autonomy for the country's affairs if equilibrium between the neighbouring great powers or a momentary power vacuum would allow it. However, the number of options declined as soon as one

24 T'ovma Arcruni, Patmut'iwn III, 1, ed. Patkanean, transl. Thomson, pp. 189-19o.

25 Thomson/Howard-Johnston, Sebeos I, p. 21, n. 154; Preiser-Kapeller, "Kaysr", p. 200.

26 Sebēos c. 11, 16 and 20, ed. Abgaryan, pp. 78, 13-14, 87, 26 and 92, 22-24, tranls. Thomson/ Howard-Johnston, Sebeos I, pp. 21, 32 and 39; Preiser-Kapeller, "Kaysr", pp. 200-201.

27 Sebēos c. 41, ed. Abgaryan, p. 134, 1, transl. Thomson/Howard-Johnston, Sebeos I, p. 94.

28 Garsoïan, "The Aršakuni Dynasty", p. 79; cf. also Toumanoff, Studies, pp. 147-259 (on the various aristocratic families); Whittow, Making of Byzantium, pp. 201-203; Pohl, Staat und Herrschaft (on the concepts of state and statehood under such circumstances).

29 Cf. Kafadar, Between Two Worlds, pp. 125-126, for this phenomenon; see also Garsoïan, "Armenia in the fourth Century"; Preiser-Kapeller, "Kaysr", p. 201; Thomson, "Armenia", pp. 156-160 and 171-172; Greenwood, "Armenian Neighbours", pp. 333-336; cf. also Hewsen, Atlas, map 63 .

3o Etišē IV, ed. Tēr-Minasean, p. 93, transl. Thomson, p. 145. On the issue of "trans-local families" see also Harzig/Hoerder, Migration History, pp. 123-126. 
imperial power achieved predominance in the region; then, individually or at large, the aristocracy sometimes had to choose between collaboration, resistance, or emigration.

\subsection{Deliberate and Forced Noble Mobility}

Within this framework, noble mobility towards the neighbouring imperial spheres became an essential element of the strategies of individuals and of aristocratic houses. As Tim Greenwood has stated, recurring motives in the depiction of the deeds of Armenian aristocrats in our period are "the service to an external authority, the titles and material rewards available to the individual princes and instances of direct contact between Emperor and client."32 As I demonstrated in an earlier study, for the "greatest nobles," their rank within the Armenian aristocracy became manifest due to its recognition by the Emperor, the Great King or the Caliph, performed in personal encounters either during imperial campaigns in Armenia or in most cases during receptions in the imperial capital. Especially Armenian sources emphasise that noblemen were permitted to stay near the monarch and dine with him and received material rewards from his hands. As within the court societies in Constantinople, Ctesiphon or Baghdad, "the public display of proximity to an Emperor mattered."33

Noble mobility towards one of the imperial spheres could become long lasting or permanent if service for and integration into the elite of an empire seemed very attractive and/or if the alternative of remaining in Armenia respectively a part of Armenia under suzerainty of another imperial power was less inviting. This was especially the case when aristocrats or entire noble houses had compromised themselves in the eyes of local imperial authorities by participating in attempts to remove foreign suzerainty, often provoked by efforts of the imperial centre to enforce stronger political and economic control (Roman Armenia in the period of Justinian, Arab Armenia in the 8th and 9th century) or religious conformity (Persian Armenian in the $5^{\text {th }}$ century, Byzantine Armenia in the 6th and 7th century). Under changing circumstances, aristocrats were also willing to cross borders several times. ${ }^{34}$

Also measures of the imperial suzerain to enforce mobility by ordering the relocation of noblemen and their armed retinues to other theatres of war could motivate individuals to evade them by crossing borders. After the

31 For noble mobility in the Western Middle Ages, cf. Hoerder, Cultures in Contact, pp. 6o-62.

32 Greenwood, “Sebeos", p. 355.

33 Preiser-Kapeller, "erdumn, ucht, carayut'iwn"; Kelly, Later Roman Empire, p. 26; cf. also Elias, Die höfische Gesellschaft, pp. 145-161; Magdalino, "Court Society", p. 216.

Preiser-Kapeller, "erdumn, ucht, carayut'iwn". 
restoration of Xusro II on the Sasanian throne with the help of Emperor Maurice, Byzantium in 591 gained suzerainty over most of former Persarmenia up to a line near the capital of Dvin (see Map 12.1). ${ }^{35}$ The emperor, eager to recover control over the Balkans in the face of the advance of the Avars and Slavs, ${ }^{36}$ transferred many troops from the East to Thrace and equally tried to recruit soldiers among the Armenians. Various aristocrats, convinced by means of promises and presents or of force, marched with their troops to Constantinople, presented themselves to the emperor, and then fought against his enemies. However, some nobles reacted with rebellion and, after its failure, with flight into the Persian Empire. ${ }^{37}$ In the history attributed to Sebēos we find, as we have seen, an Armenian interpretation of the empire's policy in the form of the letter allegedly written by Maurice to Xusro II (see above). Sebēos also informs us that in the year 602 the Emperor ordered the resettlement of 30,000 households from Armenia in Thrace, but this plan was not executed because of Maurice's overthrow. ${ }^{38}$

Thus, while honourable and lucrative service to the Emperor abroad earned praise in the Armenian historiography, measures to enforce stronger imperial control and mobility were interpreted as plans to destroy the socio-political framework of the country. Limitations both to the presence of imperial authority (especially armed forces) as well as to the spatial range of mobility in imperial service were also core conditions under which the Armenian nobility at large under the leadership of T'ēodoros, lord of the house of Řštunik', exchanged Byzantine suzerainty for the Caliph's one in 653:

35 On this important treaty cf. Theophylact Simocatta v, 15, 2, ed. de Boor/Wirth, p. 216, 10-13 and IV, 13, 24, ed. de Boor/Wirth, p. 177, 23-27, transl. Schreiner, p. 302, n. 590; Sebēos c. 12, ed. Abgaryan, p. 84, 24-33, transl. Thomson/Howard-Johnston, Sebeos I, pp. 28-29 and II, p. 171; Narratio de rebus Armeniae § 94, ed. Garitte, p. 39, 235-237 and pp. 236-237; T'ovma Arcruni, Patmut'iwn II, 3, ed. Patkanean, p. 148; Honigmann, Ostgrenze, pp. 28-37; Christensen, Iran, p. 445; Grousset, Arménie, pp. 249 and 251-253; Goubert, Byzance, pp. 167-170 and 290-302; Adontz/Garsoïan, Armenia, pp. 179-182; Laurent/Canard, Arménie, pp. 40-41; Garsoïan, "Marzpanate", pp. 108-109; Beihammer, Nachrichten, pp. 22-23 (n. 14); Garsoïan, Grand schisme, pp. 264-267; Redgate, Armenians, p. 157; Greatrex/Lieu, Eastern Frontier, pp. 172-174 and 294, n. 54; Greenwood, "Sebeos", p. 335 (with n. 51); PreiserKapeller, "Magister Militum", pp. 349-350; Thomson, "Armenia”, p. 169; Greenwood, "Armenian Neighbours", p. 337; Dölger, Regesten, nr. 104; cf. esp. Hewsen, Atlas, map 69.

36 Cf. the papers by Johannes Koder and Florin Curta in the present volume.

37 Cf. also Greenwood, "Armenian Neighbours", pp. 337-338.

38 Sebēos c. 30, ed. Abgaryan, p. 105, 28-33, transl. Thomson/Howard-Johnston, Sebeos I, p. 56 and II, pp. 190-191; Grousset, Arménie, pp. 264-265; Goubert, Byzance, pp. 209-210; Charanis, "Transfer of population", p. 142; Ditten, Ethnische Verschiebungen, pp. 134-135; Garsoïan, "Marzpanate", pp. 109-110; Greatrex/Lieu, Eastern Frontier, pp. 178-179; PreiserKapeller, “Kaysr”, p. 195; Dölger, Regesten, nr. 137. 
Now the prince of Ismael spoke with them and said: "Let this be the pact of treaty between me and you for as many years as you may wish. I shall not take tribute from you for a three-year period. Then you will pay (tribute) with an oath, as much as you may wish. You will keep in your country 15,00o cavalry, and provide sustenance from your country; and I shall reckon it in the royal tax. I shall not request cavalry for Syria; but wherever else I command they shall be ready for duty. I shall not send amirs to (your) fortresses, nor an Arab army - neither many, nor even down to a single cavalryman. An enemy shall not enter Armenia; and if the Romans attack you I shall send you troops in support, as many as you may wish. I swear by the great God that I shall not be false." 39

Yet, as we learn later, also the Arab authorities enforced mobility on a considerable number of aristocrats and their families in order to guarantee their allegiance in the form of hostages. When the Armenian nobility in 656 decided to return to Byzantine suzerainty, this proved fatal for most of these individuals, while it had the desired effect on some of the aristocrats who abstained from changing the sides:

Then when the king of Ismael [= the Caliph] saw that the Armenians had withdrawn from submission to them, they put to the sword all the hostages whom they had brought from that land, about 1,775 people. A few were left, in number about 22, who had not happened to be at that spot; they alone survived. But Mušel, lord of the Mamikoneank (...), because he had four sons among the hostages with the Ismaelites, was therefore unable to withdraw from their service. ${ }^{40}$

Until the beginning of the 8th century, the Armenian nobility, reacting to changes in the balance of power between the Caliphate and Byzantium, switched sides several times before the Arabs achieved more permanent dominion in the Armenian highlands. The relatively beneficial conditions of the

39 Sebēos c 48, ed. Abgaryan, p. 164, 27-33, transl. Thomson/Howard-Johnston, Sebeos I, pp. 135-136; cf. also Łewond c. 4, ed. Ezean, p. 14, transl. Arzoumanian, pp. 53-54; Garsoïan, "Arab Invasion", pp. 121-122; Dadoyan, The Armenians I, pp. 56-57.

Sebēos c. 52, ed. Abgaryan, p. 175, 9-12, transl. Thomson/Howard-Johnston, Sebeos I, p. 153 and II, pp. 282-284; Grousset, Arménie, p. 304; Laurent/Canard, Arménie, pp. 126-127, 242 and 402; Garsoïan, "Arab Invasion", p. 122; Redgate, Armenians, p. 168; Preiser-Kapeller, "Magister Militum", p. 359; idem, "Hrovartak", pp. 302, 311; Greenwood, "Armenian Neighbours", pp. 342-343; Dölger, Regesten, nr. 228a. On this phenomenon see in general Kosto, Hostages. 
treaty of 653 were replaced by a more strict regime with garrisons especially in the strategically important frontier regions to Byzantium and an Arab governor (ostikan) residing in the country and enforcing regular tax payments. As in most cases, different factions of the Armenia nobility reacted differently: while a group around the until then leading house of Mamikonean tried several times to remove Arab rule with violence, especially the increasingly important family of the Bagratuni followed a policy of collaboration with the Arab authorities. ${ }^{41}$ These put down all rebellions by force and executed or deported unruly individuals, often into far away regions of the Caliphate (such as Yemen). ${ }^{42}$

Under such circumstances, migration into the Byzantine Empire was again an option. The historian Łewond reports for the year 788 such a larger scale movement:

Left without property and food, naked and barefoot, (the inhabitants of Armenia) were exposed to the horrors of famine. They left their country and fled to the Greek territory to seek refuge. The mass of the population, over twelve thousand men, women, and children, as we were told, migrated from their land under the leadership of Šapuh from the house of Amatunik', Hamam his son, and other Armenian nobles with their cavalry. (...) As they crossed the river [Akampsis], the Greek Emperor Constantine [VI] was immediately notified. He called them unto him and gave the nobles and their cavalry high honours. (The Emperor) accommodated the bulk of the lower class people on good fertile lands. ${ }^{43}$

In the period under consideration, refugees were welcome, even in high numbers, if they could provide valuable manpower for military and economic purposes.

41 Cf. also Greenwood, "Armenian neighbours".

42 Łewond c. 21, ed. Ezean, p. 112, transl. Arzoumanian, p. 113; Garsoïan, "Arab Invasion", p. 129. The removal or extinction of several noble families created also opportunities for immigrating (or also converted) Muslim elites to create regional power bases within historical Armenia, cf. Ter-Ghewondyan, The Arab Emirates; Dadoyan, The Armenians I, pp. 87-90; Preiser-Kapeller, "Complex processes of migration". On interaction and cultural exchange between Christian Armenian and Muslim elites cf. also Jones, Between Islam and Byzantium; Preiser-Kapeller, "Complex processes of migration".

43 Łewond c. 42, ed. Ezean, pp. 168-169, transl. Arzoumanian, p. 149; Greenwood, "Armenian Neighbours", p. 348; Redgate, "Myth and Reality", p. 291, also on the further development of this community. 


\subsection{Byzantium as (not so) Desirable Destination}

Besides the prospect to find more beneficial conditions for living or of simply avoiding acts of revenge by irritated imperial authorities, Byzantium as Christian polity was regarded an empire of different quality in comparison with Persia or the Caliphate. The 8th century historian Movsēs Xorenac'i interprets the decision of King Aršak as well as his retainers to opt for Roman suzerainty in 387 along these lines (but highlighting also the significance of kinship ties):

So Aršak left the native kingdom of his fathers, Ayrarat, and all the part of the Persian sector, and went to rule over the western regions of our country, in the Greek sector ( $i$ bažnin Yunac'), not only because of his mother who was in the imperial capital (i kayserakan k'atak'ên), but because he thought that it was better to rule over a smaller region and serve a Christian king than to control most (of the country) and submit to the yoke of heathens. The princes of Šapuh's sector followed him with their wives and sons, abandoning each one's possessions and villages and estates. ${ }^{44}$

A similar interpretation Łewond provides when describing the deliberate emigration of Armenians from the environs of Theodosioupolis (Erzurum) on the occasion of an imperial campaign in the region in the 75os (accompanied also by the deportation of Muslim population into the Empire):

(...) the king of the Greeks [Constantine v] moved from his imperial portals with a massive multitude of followers and arrived at the city called Theodosioupolis in the region of Karin. (...) Furthermore, he took the city troops and the local Saracens, along with their families, to the land of the Greeks. Many of the inhabitants of the same districts asked the king to allow them to follow him, in order to be relieved of the heavy yoke of servitude to the Arabs. Having secured permission from (Emperor Constantine v), the inhabitants of the Armenian districts prepared themselves, packed their belongings and moved, placing their trust in the power of the dominical cross and in the glory of the King. They separated themselves (from the rest), left their homeland, and went to the country of the pious king. ${ }^{45}$

44 Movsēs Xorenac'i iII, 42, ed. Abełean/Yarut'iwnean, transl. Thomson, p. 304.

45 Łewond c. 29, ed. Ezean, p. 129, transl. Arzoumanian, pp. 123-124; Charanis, "Transfer", p. 144; Garsoïan, "Problem", p. 57. 
Yet, as already mentioned, doctrinal differences between Byzantine and Armenian Orthodoxy since the later 6th century led to an alienation between the two churches, accompanied by attempts of imperial authorities to enforce conformity with Constantinople during periods of Byzantine pre-dominance in the Armenian highlands in the 6th and 7 th century ${ }^{46}$ Afterwards, Byzantium could also be regarded as shelter of heresy and staying there could threaten the true faith of Armenian Christians. ${ }^{47}$ Katholikos Yovhannēs Drasxanakertc'i at the beginning of the 1oth century for instance explained why he decided not to follow an invitation of the emperor to Constantinople (in contrast to the Armenian king):

I decided not to go, thinking that there might be people who might look askance at my going there, and assume that I sought communion with the Chalcedonians. It was for this reason that I did not wish to go, lest I might scandalize the minds of the weak. ${ }^{48}$

Therefore, we also find in the same work of Łewond, who describes the decision of the Armenians near Theodosioupolis to move to Byzantium by placing their trust into the Christian faith of its emperor, a different interpretation of the option to emigrate to the Empire in a later episode shortly before a revolt of the nobility against the Arabs in $774 / 775$ :

Ašot son of Prince Sahak from the house of the Bagratids, did not take part in this dangerous enterprise, because he was full of wisdom and prudence. On the contrary, he kept counselling the rest to abandon the perilous enterprise (...) and think of their own security as well as that of their families. He told them: “(...) Even the Roman Empire was unable to raise its hand against this dragon (= the Arabs), and it still continues to tremble before it and has not dared to act against the dominical command. (...) you will be forced to flee from your land with your entire households (...) and live under the foreign yoke of the king of the Greeks. ${ }^{49}$

46 Cf. in general on this the magisterial study of Garsoïan, Grand schism; Mahé, "Die armenische Kirche".

47 Preiser-Kapeller, "Between New Jerusalem".

48 Yovhannēs Drasxanakertc'i 55 , § 7, ed. Zagareišvili, transl. Maksoudian, p. 198.

49 Łewond c. 34, ed. Ezean, pp. 142-143, transl. Arzoumanian, p. 132; Garsoïan, "Arab Invasion", p. 131. 


\subsection{Ecclesiastical and Learned Mobility}

Besides doctrinal issues, the Christianisation of the Roman Empire and of Armenia brought about also a new framework for mobility via the emergence of channels of ecclesiastical authority, pilgrimage and education.

From the beginning of the establishment of an Armenian ecclesiastical hierarchy in the 4th century onwards, its representatives were closely connected with neighbouring churches and church provinces. Until the end of the 4th century, the Senior Bishop (later "Katholikos") of Armenia was ordained by the metropolitan of Caesarea in Cappadocia. Armenian hierarchs took part in the ecclesiastical councils of the 4 th and $5^{\text {th }}$ centuries in Nicaea, Constantinople, Ephesus and Chalcedon. The Armenian clergy communicated also with ecclesiastics in Syria and Mesopotamia, in Georgia and Caucasian Albania and in Persia. These exchanges on doctrine and praxis of faith intensified in the period of Christological disputes between the $5^{\text {th }}$ and the $7^{\text {th }}$ century, when the Armenian church ultimately repudiated both the teaching of Nestorius (whose theological position became most prominent in Persia) and of the Council of Chalcedon (the dogma of the Byzantine and later also of the Georgian Church) and sided with the mono/miaphysite Churches of Egypt and Syria. Many of these communications have been collected in the so-called "Book of letters" (Girk' T'lt'oc'). ${ }^{50}$ From these letters and other sources we learn however that despite the rift between the churches in the 6th and 7 th century and the Arab conquest of Armenia, contacts with the Byzantine church did not break down in the 8th and gth centuries (letter of Patriarch Germanos I to Bishop Daniel of Siwnik' [ca. 720, see below], exchange of letters with Patriarch Photios [between 862 and 886, see below]). Equally, the picture of a united antiChalcedonian Christianity produced in the Armenian historiography does not withstand closer inspection as does the image of a united Armenian monarchy. The number of Armenian clergymen and laymen, who (and not only under Byzantine pressure) also in the $7^{\text {th }}$ and 8th century and later on had sympathies for the Chalcedonian creed was not insignificant. ${ }^{51}$

Clerics and monks found also their way to Palestine before and after the Arab conquest, where we encounter a vivid Armenian community in and around Jerusalem; we also possess several Armenian mosaic inscriptions from the $5^{\text {th }}$ to $7^{\text {th }}$ century, which are among the oldest epigraphic testimonies in

50 Cf. for an overview on these issues and all sources Garsoïan, Grand schism.

$5^{1}$ See most recently Garsoïan, Interregnum, pp. 55-104 (with references), and Garsoïan, "Problem", pp. 104-109 (especially on the so-called Cat'/Tzatoi, Armenian-speaking Chalcedonian communities, who somehow suffered from rejection both by the Armenian and the Byzantine-Greek Orthodoxy, see also Todt/Vest, Syria, p. 456). Cf. also Redgate, "Myth and Reality". 
Armenian language at all. ${ }^{2} \mathrm{~A}$ text attributed to a Vardapet Anastas and dated to the 7 th-1oth century lists (for sure exaggerating) 70 churches and monasteries, which had been build or bought by Armenians in Jerusalem between the 4th and 7 th century. ${ }^{53}$ At least several churches are mentioned in the exchange of letters between Modestos, the head of the Armenian community in at this time Persian-ruled Jerusalem, and Katholikos Komitas in Armenia from the year 617 , included in the history attributed to Sebēos. ${ }^{54}$ In his answer to Modestos, the Katholikos also explains the motivation and spiritual value of the pilgrimage to Jerusalem and beyond:

But know this, O beloved brother, no little consolation was conveyed to our people by the coming and going of those journeys. First, because they forgot all the troubles and sadness of this country. Secondly, because they cleansed their sins through repentance, fasts and mercy, through sleepless and unresting travelling by day and night. Thirdly, because they baptized their bodies in the water of holiness, in the fiery currents of the Jordan, whence the divine grace flowed to all the universe. ${ }^{55}$

As Komitas equally wrote, Armenian pilgrims and monks found their way to the Monastery of St. Catherine on Mt. Sinai. This is also documented by Armenian inscriptions and Armenian manuscripts ${ }^{56}$ as well as hagiographic sources: in the Narrationes de patribus Sinaïtis we find for the 7 th century an Armenian monachos named Elissaios who saw a vision of fire above the altar almost every night. ${ }^{57}$ In addition, later, the Narrationes mention a group of not less than 800 Armenians, who, together with a large number of Arabs, became witnesses of a fire vision on Mt. Sinai. ${ }^{58}$ However, Armenian clergymen travelled

52 Greenwood, "Armenian inscriptions", pp. 89-91; Vaux, "Linguistic manifestations".

53 The Armenian Pilgrim Guide, transl. in: Wilkinson, Jerusalem Pilgrims, pp. 16-17, 166-168. Cf. also McCormick, Charlemagne's Survey, pp. 57-59, 96-98. On the actual monumental evidence as well as for a systematic survey of evidence for Armenian presence from the $5^{\text {th to the }}$ 11th century see now Tchekhanovets, The Caucasian Archaeology of the Holy Land.

54 Sebēos c. 35-36, ed. Abgaryan, pp. 116-121, transl. Thomson/Howard-Johnston, Sebeos I, pp. $70-76$.

55 Sebēos c. 36, ed. Abgaryan, p.119, transl. Thomson/Howard-Johnston, Sebeos I, p. 74.

56 Cf. Vaux, "Linguistic manifestations". See also Stone, "The Greek Background", pp. 194202; Redgate, "Myth and Reality", p. 285.

57 Prosopographie der mittelbyzantinischen Zeit Online, nr. 1508; Narrationes de patribus Sinaïtis cap. XXXVII, ed. Nau, p. 81 .

$5^{8}$ Prosopographie der mittelbyzantinischen Zeit Online, nr. 10204; Narrationes de patribus Sinaïtis cap. XXXVIII, ed. Nau, pp. 81-82. 
even beyond the Arab and the Byzantine sphere to Italy and even to France and Central Europe, where we find their traces in Latin sources, as RalphJohannes Lilie has demonstrated, for instance. ${ }^{59}$ Thus, the geographical range of Armenian ecclesiastical mobility is comparable with the aristocratic one.

In addition, learning in Armenian Church was strongly influenced by both Greek and Syriac Christianity, whose centres of education could be found in the Roman Empire. The establishment of such educational links was attributed by the $5^{\text {th }}$ century historian Agat'angełos already to the first Christian king of Armenia Trdat III in the early 4th century, who allegedly had founded schools in order to teach pupils in Syriac (yAsori dprut iwn) as well as in Greek (i Hellen). ${ }^{60}$ Soon after Mesrob Maštoc ${ }^{c}$ at the beginning of the 5 th century had developed an alphabet for the Armenian language, a large-scale translation activity from Syriac and from Greek started, which also influenced the linguistic development of Armenian literature. Scholarship speaks of a "Hellenising school" especially in the 6th century. ${ }^{61}$ Still for Movsēs Xorenac'i in the 8th century, "Greece (was) the mother or nurse of all sciences". ${ }^{62}$ Armenians had studied at places of education in the Roman Empire already in the 4th century. Ammianus Marcellinus mentions that one of his schoolmates in Antioch in the 330s/340s was the princely heir of the Satrap of Corduene (in Southern Armenia), held as hostage in Syria. ${ }^{63}$ Another one of the Armenian Satraps in this region was Thomas, who in the early 6th century was educated "in the wisdom of the Greeks" in Berytus and Antioch. ${ }^{64}$

The desire for Christian education intensified scholarly mobility. Koriwn, disciple and biographer of Mesrob Maštoc', in the early 5th century and the historian tazar P'arpec' $i$ in the late 5 th century studied in Constantinople, which the latter praises as source of "flows of wisdom (...). Prominent scholars from all parts of the Greek Empire hurry to go there". ${ }^{65}$ The famous 7 th century

59 Lilie, "Sonderbare Heilige".

6o Agathangelos (armen.) § 840, ed. ed. Thomson, p. 374.

61 On the development of the Armenian alphabet now see the contributions in Seibt/Preiser-Kapeller, The Creation of the Caucasian Alphabets. On the "Hellenising School" see Terian, "The Hellenizing School", pp. 175-186; Weitenberg, "Linguistic continuity", pp. $447-458$.

62 Movsēs Xorenac'i i , 2, ed. Abełean/Yarut'iwnean, transl. Thomson, p. 68; Terian, "Xorenac'i and Eastern Historiography", pp. 101-141; Thomson, "Constantinople in Early Armenian Literature", pp. 20-34; Preiser-Kapeller, "Between New Jerusalem", pp. 65-66.

63 Ammianus Marcellinus 18, 6, 20, ed. Seyfarth; Treadgold, Early Byzantine Historians, p. 52.

64 The Prosopography of the later Roman Empire III s. v. Thomas, p. 17, with further references.

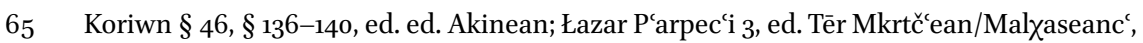
p. 4, transl. Thomson, p. 37; Preiser-Kapeller, "Between New Jerusalem”, pp. 66-67. 
scholar Anania of Širak reports in his so-called "autobiography" about his educational journey to Theodosioupolis and Trebizond in the 630s, where he studied especially mathematics with a teacher named Tychikos, who in turn under the Emperors Tiberius and Maurice had served in the Byzantine Army in Armenia, where he had learned the Armenian language, before his studies had led him to Jerusalem, Alexandria, Rome and Constantinople (see Map 12.3). ${ }^{66}$

\subsection{Non-Elite Mobility and Borderlands}

Therefore, we encounter a multitude of voices regarding mobility and migration in the Armenian sources, often within the same text. However, as indicated above, we are (besides pilgrims, who also may have come from a non-elite stratum of society) mostly informed about (military, ecclesiastical or educational) elite mobility and elite considerations.

One example for the mobility of an artisan from Armenia to Byzantium is Trdat, architect and mason, who according to the Armenian historian Stephen of Taron travelled to Constantinople and was entrusted with the restoration of the Hagia Sophia, which had been damaged by an earthquake in October 989 . However, to our disappointment, his accomplishment found no echo in the Byzantine sources, which mention the damage and reconstruction of the Hagia Sophia, but not Trdat. At the same time, we learn from Stephen of Taron that Trdat was the architect of the church of the Armenian Katholikos in Argina and of the Cathedral of Ani for King Smbat II Bagratuni; we can therefore assume that he was closely connected with the Armenian elite. ${ }^{67}$

Nevertheless, as we have seen, in many cases aristocrats moving across borders were accompanied by their retainers, both noble and not noble, and sometimes their families. Bringing with him valuable manpower of course strengthened also the position of a nobleman in his negotiations with the authorities of his destination. ${ }^{68}$ Even more, imperial authorities relied on these networks of allegiance when attempting to mobilise larger numbers of soldiers or settlers for their purposes. Again, the period of Byzantine control over most of Armenia under Emperor Maurice between 590 and 602 provides an illustrating example:

66 Cf. Greenwood, "Reassessment". See also Hewsen, "Science in Seventh-Century Armenia”.

67 Prosopographie der mittelbyzantinischen Zeit Online, nr. 28370; Stephen of Taron III, cap. 11 and 27, ed. Mal $\chi$ asean, transl. Greenwood, pp. 239 and 289.

68 For an example of the re-location of non-elite population within Armenia by Katholikos Nersēs III "the Builder" (641-661), whose re-settled peasants on newly cultivated land, cf. Garsoïan, Interregnum, p. 38 (with references). 
He (Emperor Maurice) further commanded all the cavalry from Armenia to assemble, and the chief nobles, (and those) who were experienced and capable of standing firm and fighting in battle in the line of spearmen. He also ordered other forces to be brought from the land of Armenia in great numbers, all of them willing and of elite stature, to be formed into battalions and that, equipped with arms, they should all cross to the land of Thrace against the enemy, and Mušeł Mamikonean as their general. ${ }^{69}$

On another occasion during the reign for Maurice we learn that these ties of allegiance between noble commander and retainers could also work to the detriment of imperial interests, since they enabled them to follow own interests also after having moved into the imperial sphere. In this episode, the Emperor has to use considerable diplomatic and material resources to separate the mass of soldiers from their aristocratic leader:

At that time, another command came from the Emperor to seek out again and find from Armenia elite armed cavalry, 2,000 in number, and put them under two reliable men, and to despatch them in great haste. They sought out and chose 2,000 armed men and put these 2,000 under two reliable men: 1,00o to Sahak Mamikonean und 1,00o under the command of Smbat Bagratuni, son of Manuēl. (...) Sahak set out, brought his force to the palace, and presented himself to the king. But when Smbat reached Xałtik', he baulked, because his force had become frightened en route, not wishing to go to that place (= Thrace) in compliance with the king's request. The king was informed of these events. Then through letters ( $h r o-$ vartaks) and trustworthy messengers he promised with an oath to send him back promptly to his own country with great honour. He also promised great rewards and gifts to the troops, and in this way he cajoled them into reconciliation. They proceeded in unity and presented themselves to the king. The king fully equipped the troops and despatched them to the borders of Thrace; Smbat he sent in great honour back to the land of his own people with many gifts. ${ }^{70}$

69 Sebēos c. 18, ed. Abgaryan, p. 9o, 16-22, transl. Thomson/Howard-Johnston, Sebeos I, p. 36, and II, pp, 176 and 178; Garsoïan, "Marzpanate", p. 109; Preiser-Kapeller, "Kaysr", pp. 193194; Dölger, Regesten, nr. 108b.

70 Sebēos c. 20, ed. Abgaryan, p. 91, 32-34, transl.Thomson/Howard-Johnston, Sebeos I, p. 38; Dölger, Regesten, nr. 89a and b. 
Yet, non-noble mobility was possible without or against the wishes of imperial authorities, especially since borders in this period were no "iron curtains", often not even clearly defined. This was also true for the Roman-Persian border in the 6th century as described by Procopius in his book on buildings:

On the way from Kitharizon to Theodosioupolis and the other Armenia lies a region called Chorzane; it extends over a march of three days and it is not separated from Persia by a lake, a river or mountains, which would impede the crossing of a pass but the borders of the two merge. Because of this the inhabitants, whether subjects of the Romans or of the Persians, do not fear one another or suspect mutual attacks but even engage in intermarriage, hold common markets for their daily needs and run their farms together. Whenever the military commanders on each side lead an army against the other because their rulers instructed them to do so they find their neighbours unguarded. The densely populated settlements are very close to each other and from old times there were no mounds anywhere. ${ }^{71}$

Emperor Justinian later tried to secure and control the frontier in this region by the construction of a fortress, since Persian armies had criss-crossed the area relatively unimpededly in an earlier war.

Especially where more densely settled areas met, there was also a higher frequency of cross-border interaction and of possible diffusion of information, against the wishes of official authorities. Deserted or sparsely settled areas on the contrast may have constituted obstacles for the dispersion of information. ${ }^{72}$ The military handbook attributed to Emperor Maurice ("Strategikon") from the period around 600 advises marching through less settled areas in order to conceal the movement of troops, but only for smaller scale armies. ${ }^{73}$ Supplying larger numbers of troops from less densely settled and less cultivated areas would have caused severe logistic problems. According to this logic, along the Byzantine-Arab frontier in the 7 th and 8th century there emerged a zone of deserted and depopulated no-man's-land, which should impede the advance of larger armies, especially of the Arabs towards Byzantine territory. A Syrian Chronicle from the year 775 describes the formation of this zone on the occasion of an Arab assault in 716/717:

71 Procopius, De aedificiis III, 3, 3, 9-12, ed. Dewing. Dignas/Winter, Rome and Persia, p. 208.

72 Cf. Lee, Information and Frontier; Austin/Rankov, Exploratio.

73 Maurice, Strategicon, I, 9, ed. Dennis, pp. 106-107. 
When a great and innumerable army of Arabs gathered and surged forwards to invade Roman territory, all the regions of Asia and Cappadocia fled from them, as did the whole area from the sea and by the Black Mountain and Lebanon as far as Melitene and by the river Arsanias [Murat Nehri] as far as Inner Armenia [the region of Theodosioupolis/Erzurum]. All this territory had been graced by the habitations of a numerous population and thickly planted with vineyards and every kind of gorgeous tree; but since that time it has been deserted and these regions have not been resettled. ${ }^{74}$

In fact, these areas did not remain unpopulated, but served as zone of transfer and refuge for several groups who wished to evade political or religious authorities. One of these was the dualistic sect of the Paulicians, which (according to their own tradition) emerged in 6th century Armenia and appeared in the eastern frontier provinces of Byzantium since the 7 th century; in the face of persecutions by the state, they migrated into this "space between". Finally since the middle of the 9th century they even created their own polity around the fortress of Tephrike (today Divriği in Eastern Turkey) and fought the Byzantines as allies of the Emir of Melitene until their defeat in $871 / 872$. Paulician groups, which included significant elements of Armenian origin, then in the $9^{\text {th }}$ and 1oth century were deported to the Balkans. ${ }^{75}$ Byzantium on the contrast tolerated and even encouraged the settlement of Armenian aristocrats with their retinue in these territories. This process intensified since the early 1oth century and contributed to the restoration of settlement and administrative structures when Byzantium re-expanded into the East; the newly established, relatively small military districts then were subsumed under the terminus "mikra armenika themata". 6

From there, benefiting from the fragmentation of political power in Caliphate since the 9th century, Byzantine suzerainty expanded again over most of

74 Chronicon ad annum Christi 1234, ed. Chabot, pp. 156-157; transl. Palmer, The Seventh Century in the West-Syrian Chronicles, p. 62. Cf. also Haldon/Kennedy, "Frontier"; TerGhewondyan, The Arab Emirates, pp. 22-25; Dédéyan, Histoire, pp. 230-231; Eger, The Islamic-Byzantine Frontier.

75 Garsoïan, The Paulician Heresy; Ludwig, "Wer hat was in welcher Absicht wie geschrieben"; Ter-Ghewondyan, The Arab Emirates, pp. 22-25; Redgate, Armenians, pp. 193-195; Dédéyan, Histoire, pp. 304-305; Dadoyan, Armenians I, pp. 91-107.

76 Charanis, "Armenians in the Byzantine Empire", passim; Haldon/Kennedy, "Frontier"; Seibt, "Armenika themata", pp. 134-141; Dédéyan, "Reconquête territorial et immigration arménienne"; Dadoyan, The Armenians I, pp. 124-128. On migration of Armenians into Syria cf. Dadoyan, The Armenians II, pp. 10-20; Todt/Vest, Syria, pp. 360-361, 423, 456-457, and esp. Dédéyan, "Le rôle des Arméniens". 
Armenia in the second half of the 10th and first half of the 11th century. One after the other of the princedoms and kingdoms, which had emerged since the 9th century, was turned into a province and its elites compensated with titles and possessions in the interior of Anatolia. These annexations in many cases were also accompanied by larger scale migrations of population into Byzantine Asia Minor, as the Continuator of T'ovma Arcruni describes for the case of the Kingdom of Vaspurakan (around Lake Van) in the year 1022:

They [the Byzantines] gave them gifts, appointed them at the royal court, gave them great cities in exchange for their cities and in return for their castles, impregnable fortresses and provinces, villages, estates, and holy hermitages. So the Artsrunik', descendants of Hayk [and] Senek'erim, exchanged their ancestral homes in the year 470 of the Armenian era, and moved into Greek territory with fourteen thousand men, not including women and children, passing under the yoke of servitude to the Romans. Likewise the Bagratid Gagik, son of King Yovhannes, also exchanged his ancestral [lands] in the year 490 of the same era, and went to Roman territory. ${ }^{77}$

In the case of Vaspurakan at least the demographic impact of these migrations described in the sources can also be checked against other evidence: an actual dramatic demographic decline in the region can be detected both in core drill data from Lake Van (using the sedimentation of charcoal as proxy for human activity) as well as in the rapid decline of building activity from the 1oth century, the apex of Arcruni power, to the 11th century. ${ }^{78}$ The political and religious tensions emerging from this large scale migration of Armenians into central Asia Minor in the 11th century and its longer term significance for the emerging of another Armenian polity in Cilicia have been studied in detail elsewhere and would deserve at least a paper of their own ${ }^{79} \mathrm{I}$ therefore close this section and continue with a more detailed inspection of the mobility and networks of several mobile Armenians.

77 T'ovma Arcruni cont. IV, 12, transl. Thomson, pp. 370-371. See also Seibt, "Die Eingliederung von Vaspurakan"; Felix, Byzanz und die islamische Welt, pp. 138-141; Charanis, "Transfer of population", p. 147.

78 See Preiser-Kapeller, "A Collapse of the Eastern Mediterranean".

79 Garsoïan, "Problem”, esp. pp. 76-82, 111-124; Cheynet, "Les Arméniens", pp. 67-78; idem, Pouvoir et contestations, passim; Seibt, "Stärken und Schwächen”, pp. 331-347; Lebeniotes,

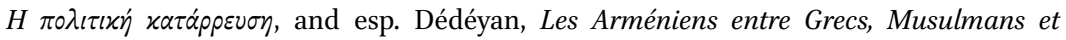
Croisés. 


\section{3}

\section{Mobilities and Networks}

Recent works of migration history have highlighted the significance of social networks and of the "multiplexity" of ties of ethnic or regional affiliation, of kinships, of politics or of economy between individuals, groups and organisations, which make up complex "migration systems". ${ }^{80}$ While our evidence does not allow us to reconstruct such webs with equal detail as for the modern period, we are able to detect and map various categories of ties for individuals, which may hint at the general complexity of connections which made Armenian mobility possible.

\subsection{Networks of Nobility and the "military labour market" of Byzantium}

The work of Procopius is a rich source for Armenian noble mobility across the Roman-Persian frontier and within the empire for the 6th century. ${ }^{81}$ Such an episode from the time around 530 illustrates several possible channels for the initiation and negotiation of mobility:

At about the same time Narses and Aratius who at the beginning of this war, as I have stated above, had an encounter with Sittas and Belisarius in the land of the Persarmenians, ${ }^{82}$ came together with their mother as deserters to the Romans; and the Emperor's steward, Narses, received them (for he too happened to be a Persarmenian by birth), and he presented them with a large sum of money. When this came to the knowledge of Isaac, their youngest brother, he secretly opened negotiations with the Romans, and delivered over to them the fortress of Bolum, which lies very near the limits of Theodosioupolis. For he directed that soldiers should be concealed somewhere in the vicinity, and he received them into the fort by night, opening stealthily one small gate for them. Thus he too came to Byzantium. ${ }^{83}$

The defection of the three brothers (who may have been members of the otherwise well-known noble house of Kamsarakan) was facilitated through the connection to an Armenian already well-established in the Byzantine elite, the famous eunuch Narses. ${ }^{84}$ It was additionally motivated by material rewards. In

8o On this term cf. Harzig/Hoerder, Migration History, p. 87.

81 Preiser-Kapeller, "erdumn, ucht, carayut'iwn". Cf. also Börm, Prokop und die Perser.

82 Cf. Procopius, Bella I, 12, 21-23, ed. Dewing I, p. 101.

83 Procopius, Bella I, 15, 31, ed. Dewing I, p. 139.

84 Cf. The Prosopography of the later Roman Empire III s. v. Narses I, pp. 912-928, with further references. 
addition, the movement of some members of the clan across the borders of course established a trans-local kinship network, which could be used by others. Procopius allows us also to trace the further carriers of Narses, Aratius and Isaac in the military service of Justinian, which led them sometimes together, sometimes far apart from each other across the entire empire from Armenia to Palestine and Southern Egypt and to Italy and the Balkans (see Map 12.2). However, their story also highlights the dangers of imperial service, since all three of them ultimately fell fighting for Byzantium: Narses in 543 after the battle of Anglon in Persarmenia, Isaak in 546 in Italy as prisoner of war of the Goths and Aratios in $55^{2}$ fighting in Illyricum. ${ }^{85}$ Under these auspices, the decision of a group of noblemen faced with the imperial desire to transfer them to the Balkans in the period of Maurice "to extricate themselves from service to the king of the Greeks (...), so that they too would not be obliged to die in the regions of Thrace, but could live or die for their own country"86 becomes comprehensible.

The term which Armenian historians used to describe the relationship of allegiance and patronage between the Emperor or the Great King and the individual aristocrats is carayut iwn. This is the same term, which describes the allegiance of the Armenian princes to their king in earlier times. ${ }^{87}$ In that way, the Emperor took the place of the Armenian king in this relationship. For the aristocrat, carayut iwn included the obligation for military service to his lord $(t \bar{e} r)$. However, this relationship also included mutual commitments, which according to the Armenian tradition were sealed through a reciprocal oath (uxt, erdumn). Because of this oath, one side took upon itself the duties of lordship and protection, and the other those of faithful service and obedience. ${ }^{88}$ The new fiduciary relation was also manifested in ritual and material ways; the new retainer was honoured in a ceremonial reception at the court in Constantinople and received valuable presents. ${ }^{89}$ One example of such a very mobile nobleman described in the history attributed to Sebēos is Atat Xorzoruni, who crossed the border into or out of the empire several times. He started his career

85 The Prosopography of the later Roman Empire III s. v. Aratius, pp. 103-104, s. v. Isaaces 1, p. 718, s. v. Narses 2, pp. 928-929, with sources and further references.

86 Sebēos c. 20, ed. Abgaryan, p. 92, transl. Thomson/Howard-Johnston, Sebeos I, p. 39.

87 Cf. Sebēos c. 15 and 16, ed. Abgaryan, pp. 87, 2 and 88, 18 and 25, transl. Thomson/HowardJohnston, Sebeos I, pp. 32-33 and II, p. 330 (s. v. submission - tsarayut'iwn); Adontz/Garsoïan, Armenia, pp. 349 and 516, n. 49; Buzandaran Patmut'iwnk', transl. Garsoïan, p. 518 (s. v.).

88 Adontz/Garsoïan, Armenia, pp. 349, 355 and 520, n. 67; Garsoïan, "The Aršakuni Dynasty", p. 78; Preiser-Kapeller, "Central Peripheries".

89 Preiser-Kapeller, "erdumn, ucht, carayut'iwn"; see for instance Sebēos c. 16 and 3o, ed. Abgaryan, pp. 88, 33-35 and 104, 22-27, transl. Thomson/Howard-Johnston, Sebeos I, pp. 34 and $55^{-} 56$ and II, p. 189 . 
as participant in a conspiracy against Persian rule in Eastern Armenia around the year 590; when this attempted rebellion failed, he crossed the border to Byzantium. There Emperor Maurikios received him with honours in Constantinople and gave him a command in the army fighting the Avars on the Balkans. Nevertheless, on his way to the troops, Atat Xorizoruni decided against joining this fight and fled across the Black Sea and Asia Minor back to Persian territory, where Great King Xusrō II received him friendly. Yet, after some years in Persian services, Atat Xor $\chi$ oruni planned to defect to Byzantium once again; this time, his intention was detected and Xusrō II had him executed. ${ }^{90}$

The motivations behind such movements could be different - some aristocrats hoped for certain benefits, others would have no other choice. The initiative for a change in the carayut iwn could come from the respective nobleman as well as from an imperial authority trying to persuade a retainer of the opposing great power to defect. ${ }^{91}$ Imperial authorities of course were anxious to impede such noble mobility when working against their interest. One instrument to do so was the demand of hostages, as did the Caliphate after its first agreement on suzerainty over Armenia with the nobility at large; nevertheless, a majority of the aristocracy defected to the emperor in 656 (see above). While it was impossible to stop such a mass defection without an equally massive use of force, individuals intending to cross borders could be impeded to do so when detected early enough - as in the case of Gurgēn Arcruni in 856, whose correspondence with the Byzantine emperor became known to Arab authorities, who had him arrested. ${ }^{92}$ In the peace treaty of 562 , Byzantium and Persia agreed that "those who in time of peace (between the two empires) defected, or rather fled, from one to the other shall not be received, but every means shall be used to place them, even against their will, in the hands of those from whom they have fled." 93 Yet, already soon afterwards, the temptation to weaken the competing empire by depriving it of important clients was too strong for both signatories.

The persisting importance of ties of kinship and ethnic affiliation in this regard is also documented for late periods; according to the 11th century Arab

90 Sebēos c. 30, ed. Abgaryan, pp. 104-105, transl. Thomson/Howard-Johnston, Sebeos I, p. 55.

91 For the material gains from imperial service which surely enhanced its attractiveness $\mathrm{cf}$. also Oikonomides, "Title and Income", pp. 202-206.

92 T'ovma Arcruni, Patmut 'iwn III, 13, ed. Patkanean, transl. Thomson, p. 267; Greenwood, "Photius", 130-32, and idem, "Armenian Neighbours", p. 351; Preiser-Kapeller, "erdumn, ucht, carayut'iwn", pp. 160-161; Dölger, Regesten, nr. 453.

93 Menander Protector, fr. 6, 1, ed. Blockley; Güterbock, Byzanz und Persien, pp. 81-92; Greatrex/Lieu, Eastern Frontier, pp. 132-133 (translation); Dignas/Winter, Rome and Persia, p. 142 (translation). 
Melkite historian Yahyā of Antioch, the conquest of the Arab fortress of Rhabaine in Northern Syria in 980 was brought about by a female Armenian slave in the fortress, who got in contact with her relatives in the Byzantine Army and helped them to cross the walls and to occupy the citadel. ${ }^{94}$

However, as we have indicated above in the case of the rebellion of Smbat Bagratuni and his troops against Emperor Maurice, the same networks of kinship and ethnic affiliation, which had supported noble mobility in the interest of the empire, could also be effective against them. One illustrative example comes again from Procopius in the shape of Artabanes, scion of the Armenian royal house of the Arsacids (see Map 12.2). He first appears in the year 538/539 in the region of Armenia interior, controlled by the Romans; there the descendants of the last Arsacid king still had considerable possessions and traditional tax privileges. ${ }^{95}$ When these prerogatives were abolished and Armenia interior turned into a province by Emperor Justinian, the Armenian nobility stood up in an armed rebellion, which the magister militum Sittas was ordered to quell. ${ }^{96}$ Among these rebels was also Artabanes, who first excelled himself by murdering the imperial governor Akakios and then by killing Sittas in hand-to-hand combat. ${ }^{97}$ Yet, the imperial forces proved insurmountable, so that Artabanes and his clan had to flee to the Persian Empire, where contacts already had been established with Great King Xusrō I. Nevertheless, before 545, he and many noblemen returned to Roman soil, bowed to the Emperor and joined the imperial army; one can assume that the conditions for the imperial pardon had been negotiated in advance, although we receive no information on this. Together with his brother Ioannes, his cousin Gregorios and other troops of Armenian origin, Artabanes in 545/546 was sent to recently conquered North Africa. There they soon found themselves involved in the rebellion of the $m a-$ gister militum Guntharis (a commander of Germanic origin), who seized power

94 Cf. Prosopographie der mittelbyzantinischen Zeit Online, nr 22695, and Todt/Vest, Syria, p. 1624 (with sources); Dölger, Regesten, nr 766c.

95 Cf. Güterbock, "Römisch-Armenien”, pp. 12-20; Toumanoff, Studies, pp. 133-134; Blockley, "Division"; Greatrex, "Partition"; Greatrex/Lieu, Eastern Frontier, pp. 28-30; PreiserKapeller, Verwaltungsgeschichte, pp. 45-48; Thomson, "Armenia”, pp. 157-159; Settipani, Continuité des élites 111-113; Ayvazyan, Armenian Military; cf. also Hewsen, Atlas, maps 65 and 66.

96 Cf. also Procopius, Bella II, 3, 35-36, ed. Dewing, p. 281.

97 Procopius, Bella II, 3, 25-26, ed. Dewing. Cf. Adontz/Garsoïan, Armenia, pp. 142-164, $3^{*}$ $34^{*}$ and $37^{*}-38^{*}$; Toumanoff, Studies, pp. 174-175, 196-197; Garsoïan, "Marzpanate"; Redgate, Armenians, pp. 155-156; Lounghis/Blysidu/Lampakes, Regesten, nr. 1078 and 1108; Preiser-Kapeller, Verwaltungsgeschichte, pp. 59-63; Preiser-Kapeller, "Magister Militum"; Preiser-Kapeller, "erdumn, ucht, carayut'iwn", pp. 151-154, and Ayvazyan, Armenian Military. 
in Carthage and declared himself independent from Constantinople. Artabanes with his troops joined Guntharis after having received some guarantees, but secretly plotted his assassination together with his relatives and the imperial official Athanasius. ${ }^{98}$ The plan succeeded in 546 and Artabanes was appointed magister militum per Africam by the emperor. Soon he returned to Constantinople according to his own wishes, where he planned to marry Praeiecta, a niece of Justinian, whom he had got to know in Africa after Guntharis had killed her first husband Areobindus. Thereby, he would have joined the imperial clan and could have hoped for even higher honours, after he had already received the consulate. According to Procopius, Artabanes even dreamed about obtaining the imperial crown (basileia). Yet, these hopes were balked when an earlier wife of Artabanes appeared in the capital und effected with the support of Empress Theodora that he received her back into his household. Frustrated, Artabanes let himself roped in into a conspiracy by his relative Arsakes together with another Armenian, Chanaranges, who intended to replace Justinian with his cousin Germanus. ${ }^{99}$ The conspiracy was detected, yet Artabanes was not severely punished by Justinian; instead, already in $55^{\circ}$ he was appointed magister militum per Thracias and sent first to Sicily and then to Northern Italy, where he served under the command of another prominent Armenian, the eunuch Narses. After 554, we lose his track in the sources.

The life story of the noble migrant Artabanes as depicted by Procopius for mere 15 years demonstrates remarkable dynamics of Armenian noble mobility, both spatial and social, within 6th century Byzantium. On the one side, we observe a stunningly rapid integration into the imperial Roman elite and almost into the imperial family itself; on the other hand, Artabanes in the most crucial and dangerous moments of his career - the rebellion against Roman rule in Armenia interior, the plot to murder Guntharis and the conspiracy against Justinian - relies on networks established by kinship and common Armenian origin (see 12.1 and 12.2).

Artabanes is not a single case for Byzantium in this regard - and similar observations can be made for other Armenian noblemen who made their career in the Persian Empire after having defected from the Roman side such as Smbat Bagratuni, whom we have already encountered above with his rebellious troops in the time of Emperor Maurice. After leading another rebellion in Roman Armenia, deportation to Constantinople and (similarly to Artabanes) military service for the emperor in Africa, he defected to Persia and within a

98 Procopius, Bella IV, 27, 11-19, ed. Dewing.

99 Procopius, Bella viI, 32, esp. 7, ed. Dewing IV, pp. 420-437, esp. 422-423; cf. also Meier, Das andere Zeitalter Justinians, pp. 261-262, on this conspiracy. 
few years achieved a most honoured position at the court of the Sasanian Great King Xusrō II, who awarded him with the title "Xosrov Šum" (Xusrō's joy). In addition, Smbat relied on an already existing network of Armenian noblemen and their retinues in the service of the Sasanians. ${ }^{100}$ The ability of the same Armenian noblemen "to fit in" both a the courts in Constantinople and in Ctesiphon was based on these networks, but also on an "aristocratic koine", a language of ritual exchange mutually understandable across borders in order to establish and maintain ties of patronage and loyalty in the wide area from Byzantium to Central Asia. We also have cues that the Christian nobility in the Caucasus region considered itself part of a more far-reaching noble tradition: in his history of the Armenians, Movsēs Xorenac'i reports the stories of origin of 50 of the most important noble houses, which I systematically surveyed. More than $50 \%$ related themselves (or were related by Xorenaci) to the eponymous ancestor of the Armenians Hayk respectively to other "autochthonous" ancestors. However, a large number of families traced themselves back to royal or significant noble houses of neighbouring countries such as Georgia, Caucasian Albania, Mesopotamia or - most prominently Persia. Connections to even more remote regions were created with ancient Israel respectively Canaan, Bulgaria or even the royal house of China. ${ }^{101}$ Therefore, mobility and trans-local connections were deeply integrated into the traditions of the Armenian nobility.

The military "labour market" of Byzantium provided opportunities for aristocrats and non-aristocrats also in the centuries after the Arab expansion. ${ }^{102}$ Around $75^{\circ}$ Kūšān al-Armanī, commander in Arab services in the region of Armenia IV, defected to Byzantium and was made strategos by Emperor Constantine v. He conquered and plundered Theodosioupolis (Erzurum); many of the captured Armenians were settled in Cappadocia. Together with some of them, Kūšān returned into the Arab sphere some years later, which again demonstrates the double-edged validity of ties of ethnic affiliation. ${ }^{103}$

100 Preiser-Kapeller, "erdumn, ucht, carayut'iwn"; Preiser-Kapeller, "Vom Bosporus zum Ararat". On Smbat Bagratuni now see also Pourshariati, Decline and Fall, pp. 136-140, 275, 297-298, 303; Settipani, Continuité des élites, pp. 331-333.

101 Cf. Preiser-Kapeller, "Vom Bosporus zum Ararat"; Preiser-Kapeller, "Central Peripheries". See also the royal Armenian, Arsacid parentage claimed for Emperor Basil I (867-886) in the biography created by his grandson Constantine vir Porphyrogennetos and adopted also in later historiography: Theophanes Continuatus, c. 2-3, ed. Ševčenko, pp. 10-19, esp. c. 3, lns. 23-24, ed. Ševčenko, p. 18.

102 Cf. also Garsoïan, "Problem", p. 64: "the Armenian career par excellence was that of military service".

103 Prosopographie der mittelbyzantinischen Zeit Online, $\mathrm{nr}$ 4169, with further references. 
Despite such defections, Byzantium in the 8th century employed Armenian noblemen in leading commanding positions on a significant scale; as Theophanes informs us for the year 778 , during a successful campaign of the thematic armies of Anatolia against Germanikeia under the supreme command of Michael Lachanodrakon, the army of the thema Anatolikon was commanded by Artabasdos (maybe Artawazd Mamikonean, who left Armenia after a rebellion in 771), the Opsikion by Gregorios tou Mousoulakiou (maybe also a Mamikonean, son of Mušeł) and the Boukellarion by Tatzates (Tačat Anjevac'i, who had defected to Byzantium around $75^{\circ}$, but in 782 returned to Armenia, where he became presiding prince in Arab services and died in 785 in battle against the Khazars). ${ }^{104}$

Desired qualities for military men were of course strength and bravery. Theophylaktos Abastaktos, a soldier of Armenian origin, saved the life of Basil I in a battle against the Paulicians and received a position in the service of the Emperor. Theophylaktos became father of the future Emperor Romanos I Lakapenos. ${ }^{105}$ Early in the reign of Basil I's son Leon VI (886-912) an Armenian nobleman Azatos or Azotos with the telling nickname "Makrocheir" ("with big hands", "with long arms") came to Constantinople with his retinue. His impressive stature prompted the emperor to make Makrocheir exarchos of the guard regiment of the Exkoubites. In 896, Azotos fell in the battle of Boulgarophygon against the Bulgarians. ${ }^{106}$

In the retinue of Azotos was also Melias (Arm. Mleh), who survived the Battle of Bulgarophygon and returned to Armenia. However, around 904 he most probably was again in Byzantine services and fought together with Eustathios Argyros in the East. Shortly afterwards, both of them fell from favour. In 907/908, Melias together with four other Armenian noblemen, Ismael and the three brothers Baasakios, Krikorikes and Pazunes, was in exile at the court of the Emir of Melitene, but returned to the Byzantine Empire via the intermediation of Eustathios Argyros, who had regained imperial favour before. All five Armenians then received commands at the Eastern frontier. Leon vi made Melias tourmarches of Euphrateia, ta Trypia and "eremia", the deserted nomans-land at the frontier. Between 909 and 912 Melias fortified and resettled the town of Lykandos together with his Armenian retinue, and used it as basis for further operations against the Arabs. In 917 Melias together with his retinue

104 Theophanes, ed. de Boor, p. 451, 12-27; see also for Artabasdos Prosopographie der mittelbyzantinischen Zeit Online, nr 640, for Gregorios tu Musulakiu nr 2407; for Tatzates nr 7241, for Michael Lachanodrakon nr 5027. See also Łewond c. 39, ed. Ezean, p. 159, transl. Arzoumanian, p. 143, and Tritle, "Flight".

105 Prosopographie der mittelbyzantinischen Zeit Online, $\mathrm{nr} 28180$, with further references.

106 Prosopographie der mittelbyzantinischen Zeit Online, nr. 20643, with further references. 
again fought the Bulgarians on the Balkans, where the Battle at the Acheloos ended with another Byzantine defeat. He then executed further campaigns at the Eastern border; his greatest success was the conquest of Melitene in 934 together with Ioannes Kourkouas, equally of Armenian origin. ${ }^{107}$ These campaigns and migrations marked also the beginning of the emergence of the above-mentioned mikra armenika themata. At the same time, they illustrate the impact of network mechanisms similar to those we have inspected for the earlier period.

\subsection{Networks of Learning and Commerce}

Some information on non-military networks across borders in the 7th century we obtain from two texts of the already mentioned Armenian scholar Anania of Širak. In one, he describes how he as young student in the 630s, dissatisfied with the quality of education in his homeland, set out for Byzantium to find an adequate instructor. He first travelled to Theodosioupolis/Karin (Erzurum) and the in the province of Armenia quarta (the region around Martyroupolis/ today Silvan), where he studied with a scholar named K'ristosatur, who could not satisfy his appetite for knowledge. Therefore, Anania intended to move to Constantinople, but on the way near Trebizond, he encountered another group of Armenian students, who (after a maritime voyage to Sinop) were on their way home. They recommended to him a professor of mathematics named Tychikos, who lived in Trebizond. Tychikos had served in the Byzantine Army in Armenia, where he had learned the Armenian language, before his studies had led him to Jerusalem, Alexandria, Rome and Constantinople. With him, Anania now studied for several years before returning to Armenia. In another short text, Ananias describes the journey of a kinsman to Balh in modern-day Afghanistan, where he purchased a very valuable pearl, which he then profitably sold piece for piece to several business partners on his way back to native Širak (a rare evidence for Armenian commerce in this period, see also below on the range of Armenian mobility)..$^{108}$

If we visualise the connections outlined in Anania's biographical narratives, we detect a multiplex, relatively complex network of ties of education, commerce, kinship, authority and patronage (see Fig. 12.3). The backbone of Anania's longer account is of course the network of education, consisting of

107 Constantine Porphyrogenitus, De administrando imperii 50, 139-148, ed. Moravcsik, pp. 238-240; Dédéyan, "Mleh le Grand". Cf. also; Prosopographie der mittelbyzantinischen Zeit Online, nr 20723 (Baasakios), 21828 (Eusthatios Argyros), 22917 (Ioannes Kurkuas), 23566 (Ismael), 24198 (Krikorikes), 25041 (Melias), 26400 (Pazunes).

108 Greenwood, "Reassessment", also with English translations of all relevant texts. 
ties between teachers and disciples. The wide connections integrated in the life story of a man who himself actually never travelled far beyond the borders of his homeland become also visible if we look at the spatial structure of the narratives (see Map 12.3).

The existence of such connections also after the Arab expansion is documented for Step'annos of Siwnikc, who between 713 and 717 travelled to Constantinople in order to "learn the Greek and the Latin language" and to study in the library of the Hagia Sophia. He translated several theological works (Dionysios Areopagites, Gregory of Nyssa) into Armenian, also with the support of a courtier of Armenian origin, the hypatos and kenarios David. ${ }^{109}$ Furthermore, Step'annos became involved in theological debates with Patriarch Germanos I, who handed over to him a letter to the Armenian Church. Afterwards he also travelled to Rome (and allegedly to Athens) before returning to Armenia, where he became bishop of Siwnik. ${ }^{110}$ His itinerary is most instructive for the possibilities still existing for mobile scholars in the early 8th century. But places of (Greek) education also still existed within the new Arab sphere of power Armenia was now part of; between 656 and 661, a Dawit from Taron translated some works of Basil of Caesarea in Damascus on the order of Prince Hamazasp Mamikonean, as we are informed in the colophon of manuscript from the Matenadaran in Erewan. We may also assume the existence of a larger Armenian colony in the city that at this time became the centre of the Umayyad Caliphate. ${ }^{111}$ Both Step'annos and Dawit also document an overlap between connections of learning and aristocratic networks towards and within the centres of imperial power, which opened important channels for their mobility.

\section{$4 \quad$ Receiving Societies: "Armenian" Communities in the Byzantine Sphere}

As we have demonstrated, service in the Byzantine Empire could provide many opportunities for material and symbolic rewards; even newcomers could be integrated into the military and court elite relatively fast. The significant share of individuals and families of Armenian background in the Byzantine elite highlighted in earlier scholarship illustrates the mobile Armenians' ability and

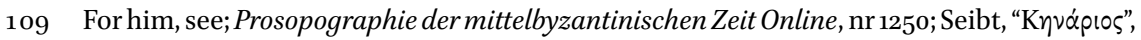
pp. $369-80$.

110 Thomson, "Constantinople in Early Armenian Literature", pp. 34-36; Prosopographie der mittelbyzantinischen Zeit Online, nr. 6989; Seibt, "Kทvápios".

111 Matenadaran ms nr 822. 
the Byzantine society's capability for integration. Nina Garsoïan in 1998 provided a magisterial synthesis on "The Problem of Armenian Integration into the Byzantine Empire"; 112 this gives us the freedom to concentrate on some selected aspects of special interest within the framework of migration history, documented by various sample cases.

\subsection{Linguistic Aspects}

Language, of course, played a significant role for the ability to "fit into" Byzantine society in all social contexts. ${ }^{113}$ While, as we have seen, many of the leading aristocrats may have spoken Greek already before their moving into the Empire or even had studied in one of the Greek institutions of learning, ${ }^{114}$ such skills cannot be assumed for all migrants, especially of non-elite backgrounds, but also for noblemen. ${ }^{115}$ Procopius tells the sorry fate of one Gilakios during the Gothic wars in Italy:

Now there was (...) a certain Gilakios of the Armenian race (Armenios genos), commander of a small force of Armenians. This Gilakios did not know how to speak either Greek or Latin or Gothic or any other language except Armenian alone. When some of the Goths happened upon this man, they enquired who he might be. For they were quite averse to killing every man who came in their way, lest they be compelled to destroy each other in fighting at night, as might easily happen. But he was able to make them no answer except indeed that he was Gilakios, a general (Gilakios strategos); for his title which he had received from the emperor he had heard many times and so had been able to learn it by heart. The barbarians, accordingly, perceiving by this that he was an enemy, made him a prisoner for the moment, but not long afterwards put the man to death. ${ }^{116}$

While bilingualism may not always have been live saving, being fluent not only in Greek, but also in Armenian was of advantage also in the service of the

\footnotetext{
112 Garsoïan, "Problem".

113 Garsoïan, "Problem", pp. 101-103. See also Vaux, "Linguistic manifestations".

114 Cf. also Greenwoord, "Corpus", and Vaux, "Linguistic manifestations", on testimonies of Greek language skills in medieval Armenia.

115 A most interesting testimony of an Armenian trying to learn Greek is a papyrus containing Greek in Armenian script, now in the Bibliothéque Nationale in Paris (inventory number BnF Arm 332); it can be dated only roughly between the $5^{\text {th }}$ and 7 th cent., cf. Clackson, "A Greek Papyrus in Armenian Script"; idem, "New Readings".

116 Procopius, Bella VII, 26, 24-27, ed. Dewing, pp. 384-386; The Prosopography of the later Roman Empire III, s. v. Gilacius.
} 
emperor, especially in his diplomatic dealings with Armenia. One hermeneutes sent on three diplomatic missions to the princedom of Taron in Western Armenia by Emperor Romanos I Lakapenos (himself of an Armenian background, as we have seen) was the protospatharios Krinites, who in turn may have stemmed from an Armenian family (a Prokopios Krinites commanded a unit of Armenians against the Bulgarians in 894; if the hermeneutes was a descendant, maintaining Armenian language skills had proven beneficial for this family). ${ }^{117}$ A counterpart to Krinites from the Armenian side may have been Theodoros, hermeneutes of the Armenians in the negotiations of the princes of Taron with Emperor Leon VI, ca. 898-90o. ${ }^{118}$

But also other individuals made their Armenian linguistic background visible; around 1000, a M $\chi i t$ 'ar together with a Philippos used a bilingual seal, which had a Greek inscription on one side ("Lord help me Machitarios and Philip") and an Armenian one on the other side ("Of me, servant [of God], M $\chi$ it'ar, and of Philip"). Most probably, it was a private seal, maybe of two business partners; but the purpose of its bilingualism remains unclear.119 A clear statement was the sponsoring of an evangeliary in Armenian language by one Yovhannēs, protospatharios and proximos of the doux Theodorokanos, which according to the colophon was finished by the writer (and probably monk) Kirakos in the year 1007 in Adrianople in Thrace. It also contains a miniature of the donator, but with a later Greek inscription, which identified a dishypatos Photeinos as donator, while the original Armenian scripture had been erased. ${ }^{120}$

\subsection{Religious Aspects - Saints and Heretics ${ }^{121}$}

This evangeliary of course also raises the questions of the religious affiliation of Armenian migrants respectively the change of affiliation. Byzantine and Armenian Orthodoxy trod different theological paths especially since the 6th century, a process that reached a first climax around 700. From the Byzantine

117 Constantine Porphyrogenitus, De administrando imperii 43, ed. Moravcsik, pp. 135-140, 169-179; Prosopographie der mittelbyzantinischen Zeit Online, nr 24200. See also s. v. Prokopios Krinites (Prosopographie der mittelbyzantinischen Zeit Online, nr 26760): and Kurtikios (Prosopographie der mittelbyzantinischen Zeit Online, nr 24215); Garsoïan, "Problem", p. 101; Martin-Hisard, "Constantinople".

118 Prosopographie der mittelbyzantinischen Zeit Online, $\mathrm{nr}$ 27644; Martin-Hisard, "Constantinople".

119 Coulie/Nesbitt, "A Bilingual Rarity”, pp. 121-123; Prosopographie der mittelbyzantinischen Zeit Online, $\mathrm{nr} 25473$ and 26662; Vaux, "Linguistic manifestations".

120 Prosopographie der mittelbyzantinischen Zeit Online, $\mathrm{nr} 28486$ and 23701, with further references; see also Vaux, "Linguistic manifestations".

121 On Byzantine-Armenian polemics in general cf. Garsoïan, “Problem”, pp. 66-82. 
side, testimony to this are several canons against Armenian ecclesiastical practices proclaimed by the Council in Trullo (Quinisextum) in 692. ${ }^{122}$ Beyond all doctrinal issues, these regulations very much intervened into customary practices both of Armenian clerics and of laymen when living under Byzantine authority. ${ }^{123}$ Even more, Canon 72 of the Trullanum declared: "An orthodox man is not permitted to marry a heretical woman, nor an orthodox woman to be joined to a heretical man. But if anything of this kind appear to have been done by any [we require them] to consider the marriage null, and that the marriage be dissolved." 124 By that time, followers of the mainstream of the Armenian Church had clearly qualified as heretics, while in the time of Justinian the (planned) marriage between the Armenian Artabanes and the emperor's niece (see above) still would not have aroused any canonical issues. From 700 onwards, on the contrast, any intention to intermarry with the Byzantine elite at least in theory would have necessitated a formal acceptance of Orthodoxy. ${ }^{125}$

Another question of course was the general tolerance of Armenian nonChalcedonian communities and especially clerics on Byzantine soil. Armenian sources report two episodes of downright persecution of Armenian clergymen for the 1oth century: in the 930s in the time of the Armenian King Abas I, "vast numbers of monks were expelled from Roman territory for the sake of orthodoxy. Coming to our land, they built many monasteries: first Kamrjajor, then the monastery called Horomosin - as if they had come from the regions of the Romansand Dpravank'. It is said that the [monastery] of the Holy Mother of God of Sanahin was built by them". It remains unclear if this persecution was commanded by the imperial centre or had a more local character; the information that one of the communities, who fled and founded the Kamrjajor-Monastery, came from Egrisi (Western Georgia), the periphery of the Byzantine-Orthodox sphere, suggests the later variant. ${ }^{126}$

122 Concilium Quinisextum, ed. Ohme, pp. 220-224, 248-250, 286 and esp. pp. 64-80 on the background to these canons; in particular relevant are Canon 32 (against the used of unmixed wine by the Armenians in the liturgy), Canon 33 (against the Armenian custom to ordain only descendants of priestly families as priests), Canon $5^{6}$ (against the eating of cheese and eggs on Saturdays and Sundays during lent), and Canon 99 (against the custom to cook meat and distribute it among the priests and worshipers on certain festive days).

123 On this period cf. also Nichanian, "Byzantine Emperor Philippikos-Vardanes".

124 Concilium Quinisextum, ed. Ohme, pp. 262-264.

125 Garsoïan, "Problem", pp. 86 and 95.

126 Vardan Arewelc'i c. 46, ed., p. 88, transl. Thomson, p. 188; Prosopographie der mittelbyzantinischen Zeit Online, nr 20006, 28465, 28466. 
Clearly from local initiative of a Byzantine Metropolitan arose a further persecution of non-Chalcedonian clergymen in the city of Sebasteia in Cappadocia in 986:

(...) and the Metropolitan of Sebasteia started to disquiet the Armenian people because of their faith. And since he had the power in his hands, he started to plague the priests because of their faith; and he also ordered to bring the protopresbyter of the city of Sebasteia in iron chains to the court of the emperor. And they killed the protopresbyter Gabriel after they had tortured him in the dungeon (...). This happened in the year 436 of the [Armenian] Era [ = March 25th 986 - March 24th 987]. And besides other priests also the two [Armenian] bishops of Sebasteia and Larissa, Sion and Yovhannēs, due to the intrigues of the same Metropolitan accepted the Council of Chalcedon and seceded themselves from the unity with the Armenians. And since then they prohibited the call to prayer of the Armenians in the city of Sebasteia until the time when Emperor Basil [II] came to the east. ${ }^{127}$

This imperial intervention in favour of the Armenian Church took place in the year 1000/1001, when Basil II on his campaign to secure the territories of the deceased prince David of Tao passed through Sebasteia. It also lets the story about the martyrdom of the priest Gabriel in Constantinople ring hollow, since the integration of Armenians and Armenian territories was one of the main aims of imperial politics in this period. ${ }^{128}$

There was also a considerable share of pro-Chalcedonian Armenians during and after the period of alienation in the 6th-7th centuries. Others would have opted for Chalcedon in order to achieve better integration into the Byzantine elite after having moved to the empire. In any case, an Armenian background was not a priori an impediment to count as "pious man" even in the eyes of the most rigorous defenders of Byzantine Orthodoxy. One case in support is Arsaber, until 808 Patrikios and Kouaistor (the highest judicial official) under Emperor Nikephoros I (a position which equally suggests a sound background in Greek education); his daughter Theodora married the later Emperor Leon v "the Armenian" (in this case, the byname was clearly used to indicate heresy).

127 Stephen of Taron III, cap. 20, ed. Malxasean, transl. Greenwood, p. 252. Cf. also Prosopographie der mittelbyzantinischen Zeit Online, $\mathrm{nr} 22031$ (Gabriel), nr 27091 (Siōn) and nr 28464 (Yōhannēs).

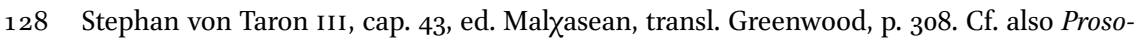
pographie der mittelbyzantinischen Zeit Online, nr 30574; Garsoïan, "Problem", pp. 70-71, 85-86; Todt/Vest, Syria, p. 423 (on the popularity of Basil II in other Armenian sources). 
Theodoros Stoudites, leading figure of the venerators of the icons during the second period of Iconoclasm, mentions Arsaber between 821 and 824 in a letter to Theodora as a pious man (indicating Orthodoxy and pro-Icon sympathies). ${ }^{129}$ Another "pious" aristocrat of possible Armenian background was Konstantinos Lips; under Emperor Leon vi, he served in several embassies to Armenia. His daughter was about to marry Apoganem, the brother of prince Grigor I of Taron, who died before the marriage ceremony. In 907 Lips founded the (of course Byzantine Orthodox) monastery in Constantinople named after him, which was consecrated with the emperor present. ${ }^{130}$

Even to sainthood rose Mary the Younger (of Bizye); according to her Vita, her father was a powerful man in Megale Armenia and at the beginning of the reign of Emperor Basil I (867-886) came to Constantinople, where also Mary was born in ca. 875 . Around 888 she married a droungarios Nikephoros, whom she got to know on the domain of her brother-in-law Bardas Bratzes (equally of Armenian background) in Mesene in Thrace. She had four sons, Orestes, Bardanes as well as the twins Baanes and Stephanos (so two children received Greek and two Armenian names). Her husband received a command in Bizye after he had distinguished himself in the war against the Bulgarians. After a pious life and plagued by her husband, Maria died in 902. ${ }^{131}$

Another "Armenian" Byzantine saint was Ioseph, who had already lived as eremite on Mt. Athos when St. Euthymios the Younger arrived there in ca. 859 . Ioseph continued his ascetic life as companion of Euthymios and was ordained as priest before he died in ca. 870. His corpse did not decay and segregated Myron chrism. ${ }^{132}$ While the presence of a large number of monks from Georgia (where the church had separated itself from the Armenians at the beginning of the 7 th century and had joined the Chalcedonian camp) on Mt. Athos especially since the foundation of the Monastery of Iviron ("of the Iberians = Georgians") in ca. 980 is well-known, also the Armenian background of some Athonite monks is documented. ${ }^{133}$ One of these, a Theoktistos, signed a charter of 1035 in Armenian letters ("I have signed with my own hand, Theoktistos") right below the Greek subscription of Theoktistos, Abbot of the Esphigmenoumonastery and also Protos of Mt. Athos (1015-ca. 1040). This had led Hr.

129 Theodoros Stoudites, Letters, ed. Fatouros, p. 538; Prosopographie der mittelbyzantinischen Zeit Online, nr 600.

130 Prosopographie der mittelbyzantinischen Zeit Online, $\mathrm{nr} 23815$, with further references.

131 Laiou, "The Life of St. Mary the Younger"; Prosopographie der mittelbyzantinischen Zeit Online, nr 24910, nr 27066. On naming practices see also Garsoïan, "Problem", pp. 96-99.

132 Prosopographie der mittelbyzantinischen Zeit Online, nr. 23511, with further references.

133 On Georgian monasticism in Byzantium since the 9th century cf. Martin-Hisard, "L'Athos",

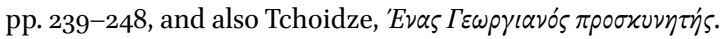


Bartikian to the assumption that this Abbot Theoktistos himself had signed a second time in Armenian and therefore was of Armenian background - a hypothesis not accepted by the main editors of this volume of the charters of the Megiste Laura. At least we encounter here a Chalcedonian Athonite monk writing Armenian. ${ }^{134}$

Even two Patriarchs of Constantinople in our period of consideration were (probably) of Armenian background. A clear case is the last Iconoclastic Patriarch Ioannes VII Grammatikos (837-843), whose father Pankratios was of noble Armenian origin (Ioannes' brother had the more "typical" name Arsaber). ${ }^{135}$ The other candidate is Patriarch Photios himself $(858-867 / 878-886)$. Son of Sergios and Eirene, both steadfast venerators of icon even in the face of imperial persecution, and brother of Tarasios, Konstantinos, Theodoros and Sergios (so no "Armenian" names in the family anymore), Photios in two letters to Ašot I Bagratuni in 878/879 (one preserved only in Armenian translation) called himself of "related blood" with the Armenian king. This has been interpreted at as least consciousness of (and in this case, deliberate allusion to) an Armenian background. In any case, also the (numerous) opponents of Photios have used his "foreign blood" and looks as argumentum ad hominem; one source, for instance, called him Chazaroprosopos ("Khazar-Face"). ${ }^{136}$

That also "Armenian" could be used as indicator for a both foreign and heterodox background in pejorative intention is clear for instance in the case of Emperor Leon v (813-820), "the Armenian", also called "Amalekites". Born as son of a Bardas, he rose to the imperial throne after a military career; he had four sons Basileios, Gregorios, Theodosios and the oldest Symbatios (the Armenian name "Smbat"), who was renamed "Constantine" on the occasion of his crowning as co-emperor. While this may indicate an effort to "fit in" by abandoning too obvious signs of "Armenian" identity, Leon's initiative to revitalise Iconoclasm earned him enduring bad press in Byzantine historiography, including his bynames. ${ }^{137}$

134 Actes de Lavra, Nr. 29, l. 20, ed. Lemerle/Guillou/Svoronos, p. 374; Prosopographie der mittelbyzantinischen Zeit Online, $\mathrm{nr} 28057$.

135 Cf. Prosopographie der mittelbyzantinischen Zeit Online, $\mathrm{nr}$ 3199, 602 and 5862, with further references.

136 Dorfmann-Lazarev, Arméniens; Shirinian, "Armenian Elites", with full references (also on the "Armenian" origin of Emperor Basil I, for whom was claimed an Arsacid, royal Armenian parentage, see also above); Greenwood, "Photius"; Prosopographie der mittelbyzantinischen Zeit Online, nr 6253, 6665, 1450, 8623, 4442, 7237, 3999, 7700 and 6672, with further references.

137 Turner, "Leo V"; Prosopographie der mittelbyzantinischen Zeit Online, $\mathrm{nr}$ 4244, with further references. 
This possible double meaning of Armenian as both "foreign" and "nonorthodox" is also evident from the Georgian Vita Ioannis et Euthymii hiberica, who mentions a certain Gvirpel (maybe a malapropism of kyr Bel), who was the financial official of a Georgian prince and became monk in the IvironMonastery on Mt. Athos, after he had converted to Orthodoxy and was rebaptized cum Armenius esset, as we read in the Latin translation of the text. ${ }^{138}$

\subsection{Language, Religion and Identity in Bari, 990}

Again, all these samples more or less pertain to the elite stratum of society. One of the rare examples for the interplay between non-elite individuals of Armenian and other backgrounds on Byzantine soil constitutes a charter produced in Bari in Southern Italy in the late 1oth century. ${ }^{139}$ Larger number of Armenian troops served in Byzantine Italy from the 6th century onwards. ${ }^{140}$ We find them especially in the centre of Byzantine rule in Ravenna. A magister militum Bahan served there in 599 and was mentioned as "glorious filius noster" in a letter of Pope Gregory the Great. ${ }^{141}$ A Paulacis, son of Stephanus and miles numeri Arminiorum (an "Armenian" regiment stationed there) was a donor to the church of Ravenna in November 639. ${ }^{142}$ Moreover, for the same period between 625 and 644 an Exarchos of Armenian background named Isaak is documented in a Greek-Latin inscription in San Vitale. ${ }^{143}$

From the end of the 9th century onwards, we also have information on the settlement of Armenians in (recently) re-conquered areas of Southern Italy. ${ }^{144}$ The document of interest was written in 990 by the Latin clericus Caloiohannes from Bari, who explained: his father Dumnellus had bought several pieces of property some years before in the plain of Celia near Bari from the Armenian women Bartisky, daughter of Moiseo Pascike and wife of the Armenian Corcus. After the death of Dumnellus Caloiohannes inherited this property, but lost the charter on the land sales. One of these pieces of land was (wrongfully) sold to the clericus Mele, son of the Armenian presbyterus Simagon. Iohannes, son

138 Vita beati patris nostri Iohannis atque Euthymii, transl. Peeters, p. 5o, ln. 12; Prosopographie der mittelbyzantinischen Zeit Online, $\mathrm{nr}$ 22534. On the re-baptism of Armenians see also Garsoïan, "Problem", pp. 72-73.

139 On this region and Byzantine Italy in general see also McCormick, "The Imperial Edge".

140 Cf. also Mutafian, "L'immigration arménienne en Italie"; Zekiyan, "Le Colonie Armene", esp. pp. 813-847.

141 PLRE III s. v. Bahan; Greg., Ep. IX 99.

142 Zekiyan, Le Colonie Armene 814-815; PLRE III s. v. Paulacis (Marini, P. Dip. 95).

143 Zekiyan, Le Colonie Armene 815 (with citation of the inscription); PLRE III A, s. v. Isaacius 8 (with further references); Garsoïan, Problem 97.

144 Dédéyan, "Le stratège Symbatikios"; cf. also Garsoïan, "Problem", pp. 56-57, with further references; Prosopographie der mittelbyzantinischen Zeit Online, $\mathrm{nr} 27443$. 
of Mele, sold a part of this piece to Cricori, the son of the Armenian Achanus. Caloiohannes now successfully demanded the return of the property from Iohannes, but agreed to allow Cricori the further cultivation of the land he had bought due to his poverty. For the confirmation of this agreement, Iohannes presented as mediator another Cricori, son of the Armenian Petrosi. The charter was signed by five witnesses, among these Leo, who signed in Greek, the sacerdos Husep, who subscribed in Armenian, and three further individuals (Andrea presbiter, Falcus presbiter and Iohannes), who subscribed in Latin. ${ }^{145}$ A visualisation of the social network emerging from the information in this documents (see Fig. 12.4) clearly demonstrates that despite a considerable amount of commercial and legal interaction between various ethnic backgrounds (indicated in the text by ethnonyms and/or languages of subscription) we encounter members of an "Armenian" colony acting within a predominantly Armenian milieu, where people have "Armenian" names, write (and speak) Armenian (although at least some of them were bi- or even trilingual up to a certain degree in order to execute the commercial and legal deals with their "Latin" and "Greek" neighbours) and attend (or work as) "Armenian" priests (of unspecified denomination). According to the document, the Armenian community in Bari was present there at least in the second generation, but maybe even longer (since the late gth century?). It is therefore hard to estimate the actual timespan of "co-habitation" of these groups, which antedated the range of interaction (and non-interaction), documented in our text. Intermarriage, not deducible from the charter of 990, can be at least assumed for another clericus armenus in Bari named Moseses, who before 1009 had built a Church of St. George in Bari. He died before October 1011, when his widow Archontissa (a "Greek" name) made a contract with his son Andreas (from his first wife) on the heritage. Her relative, the ek prosopou Silvester, supported Archontissa. The charter was produced by the clergymen and notarius Bisantius and subscribed by four witnesses: the archidiaconus Madelmus, the clergyman Romualdus, Amatos, and another Romualdus, son of the protospatharius Pardus. Here, the heritage of the Armenian priest is negotiated within a predominantly "Greek-Latin" milieu. ${ }^{146}$ These relatively detailed views on the interactions between different ethnicities in the Byzantine province within the

145 Codice diplomatico barese IV, Nr. 4, ed. Nitti Di Vito, pp. 8-10. Cf. also Achanus (Prosopographie der mittelbyzantinischen Zeit Online, $\mathrm{nr}$ 20092), Cricori (nr 21354), Iohannes (nr 23493), Caloiohannes (nr 21223), Bartisky (nr 20834), Moiseo Pascike (nr 25415), Corcus (nr 21348), Mele (nr 25031), Simagon (nr 27078), Iohannes (nr 23493), Cricori (nr 21355), Petrosi (nr 26550), Leo (nr 24305), Husep (nr 22644).

146 Codice diplomatico barese IV, nr 9 and 11, ed. Nitti Di Vito, pp. 18 and 21-24; Prosopographie der mittelbyzantinischen Zeit Online, $\mathrm{nr}$ 25429, 20549, 20392, 27076. 
non-elite stratum of society (although the clergymen and notarii definitely constituted leading figures of their local communities) are sporadic and therefore even more tantalising with regard to the modification or confirmation of linguistic, onomastic and religious aspects of identity. We also do not get any information on the possible pressure towards doctrinal conformity, for instance, from the side of state authorities.

\subsection{Byzantium, Armenians and Armenian Mobility at Large}

Beyond possible religious antagonisms mentioned also above, the already discussed case of Artabanes Arsakides had illustrated the possible tensions between the desire to integrate into the Byzantine elite and the imperial pull towards conformity on an individual level. The background to the rebellion amidst which we first encounter Artabanes in the sources demonstrates similar tensions between the imperial regime and Armenian communities at large. As mentioned above, within the Western Armenian territories which came under Roman suzerainty under the conditions of agreements with the Sasanians in the 4th century (see Map 12.1), the Arsacids and other noble families enjoyed several privileges and some agree of autonomy, especially in the South-western regions, which where under the rule of indigenous princes called "Satraps" in the sources (see also above for two of these princes studying in Antioch and Berytus). After more than a century of special status, Emperor Justinian I decided to bring about a full integration of these territories into the military and provincial framework of the Empire. The Satrapies and Armenia interior (the homeland of Artabanes) were put under the control of a magister militum per Armeniam. A few years later, all these areas together with two already existing Armenian provinces were organised into four new provinces (Armenia I-IV) and the autonomy of the Satraps and noble houses was abolished. ${ }^{147}$ Even more, a new tax regime and the Roman law system were introduced; in an edict "Concerning the order of inheritance among the Armenians" (De Armeniorum successione, 535) and in the Novella XXI (De Armeniis ut ipsi per omnia sequantur romanorum leges, 536), Emperor Justinian tried to apply the Roman law on the whole of Roman Armenia, "desiring that the land of the Armenians should prosper altogether and should differ in no way from our realm."148 Also within the new military and administrative framework, individuals of Armenian background played as significant role; this very much

147 Adontz/Garsoïan, Armenia, pp. 134 (translation) and $35^{*}$ (Greek text).

148 Adontz/Garsoïan, Armenia, pp. $142-164,32^{*}-34^{*}$ and $37^{*}-38^{*}$ (Greek texts of the two laws); Güterbock, "Römisch-Armenien", pp. 43-58; Lounghis/Blysidu/Lampakis, Regesten, nr. 1078 and 1108; Dédéyan, Histoire, pp. 196-197; Thomson, “Armenia", pp. 167-168. 
made sense from an imperial point of view, as also Malalas indicates concerning the new magister militum per Armeniam Sittas, who "enrolled indigenous scriniarii and made them his own military scriniarii in accord with an imperial rescript, having requested the Emperor to enrol natives since they knew the regions of Armenia."149 In addition, the first governors of Armenia interior as province were recruited among the Armenian aristocracy, as Procopius tells us, but not from the long-established houses, but from noblemen who recently had defected from the Persian side. ${ }^{150}$ The promotion of these "newcomers", together with the other imperial measures, incited the representatives of the "autochthonous" Armenian nobility to violent resistance. The insurgents also made contact with the Sasanian Great King Xusrō I, to whom they also escaped after the failure of their rebellion, and complained against Justinian. ${ }^{151}$ The example of the Satrapies and Armenia interior demonstrates what imperial pressure towards conformity and control could imply for the traditional framework of noble power in Armenia: the gradual reduction of autonomy, the installation of military and administrative structures, the displacement of the noble families from the region and their (attempted) integration into the empire's elite were the crucial steps of the integration of Western Armenia into the empire as a province. ${ }^{152}$ This modus operandi was applied by the empire also in following centuries vis-à-vis the noble houses of Armenia if the empire had the opportunity to win the upper hand in the struggle for the control of the country for a longer time, as it did in the late 1oth/early 11th century.

Imperial authorities were not only anxious to impose control on individuals and population within their borders, but also on their mobility within and beyond. We have already mentioned above the contractual clause of the Byzantine-Persian peace treaty of 562 regarding the limitation of defections by the imperial powers, which would have pertained especially also to Armenians, as the earlier experiences in the period of Justinian had taught. Another interesting example of imperial legislation in this regard is a rescript of Emperor

149 John Malalas 18, 10, ed. Thurn, p. 359, 12-14; Greatrex/Lieu, Eastern Frontier, p. 84; PreiserKapeller, "Magister Militum", p. 349.

150 Procopius, Bella II, 3, 1-6, ed. Dewing I, pp. 270-271; The Prosopography of the later Roman Empire III, s. v. Acacius 1, pp. 8-9.

151 Procopius, Bella II, 3, 38-40, ed. Dewing I, pp. 280-281; on the accusation of being a ruthless revolutionary, which Procopius expresses against Justinian on several occasions, cf. Meier, Das andere Zeitalter Justinians, pp. 198-199.

$15^{2}$ Cf. also Faroqhi, Ottoman Empire, p. 75: "Only after a certain lapse of time were the sons of former dynasts-turned-Ottoman-dignitaries appointed to serve in faraway provinces, while the territories held by their fathers or grandfathers were integrated into the Ottoman imperial structure, and now administered by people with no previous links to the localities concerned." 
Nikephoros II Phokas from the year 964 to an anonymous official, maybe the commander of the region of Lykandos (a region re-settled by the Armenians under Melias 50 years before, see above). This official had informed the emperor about several problems in this region, especially also on the habit of Armenian possessors of military estates to leave their property frequently without permission for longer periods. Nikephoros II Phokas ordered that property left by Armenian soldier should become property of the state already after three years (and not after 30 years as in other cases) and could be distributed among refugees or other soldiers anew after this period in order to "teach" the Armenians that they not had the freedom to leave and settle somewhere else and to return according to their own wishes, since otherwise "all the Armenian thematic armies" would dissolve. ${ }^{153}$ Once Armenian groups had migrated to Byzantium, the empire of course wanted to maintain its military and agricultural work force; even more than individual acts of defection, unauthorised mobility on a larger scale threatened the very existence of the newly established defence perimeter at the frontier.

At the same time, from a modern point of view it may seem surprising that even an absence of three years was tolerable by the authorities. Nevertheless, such relatively high limits for the absence of individuals before their property rights or other aspects of their legal status underwent a modification we also encounter in the Armenian ecclesiastical legislation. They therefore allow some inferences on the extension of (deliberate or forced) mobility at large. The Armenian Church was especially concerned with the preservation of bonds of matrimony in the case of a longer-term absence of one of the spouses. According regulations were made at a Council in the capital of Dvin in 648, after the first period of Arab incursions in the country, which had brought about larger scale displacement of people. These canons then remained valid over the centuries and were also included in the important Law code of M $\chi$ it'ar Goš from the late 12th century. According to these regulations, one was allowed to remarry after seven years, if the other spouse had been taken captive and her or his whereabouts remained unknown. While this rule regarding forced mobility pertained to both gender, the same seven-years period was applied in cases where one spouse deliberately left home (for commerce or other purposes) and was reported death. Yet, this canon acts on the assumption that only the man would undertake such a journey, while the wife would remain behind (and would be allowed to take another husband after seven years).

153 Svoronos, Les novelles, nr. 9, pp. 170-173, esp. 170, Ins. 1-11; McGeer, The Land Legislation, pp. 87-89; Dölger, Regesten, $\mathrm{nr} 720$. See also Prosopographie der mittelbyzantinischen Zeit Online, nr 31466, and Garsoïan, "Problem", p. 63. 
Finally, the regulation would also be effective if the wife found out that her husband had taken another wife in his place of destination; after seven years she would be free to marry again (one wonders if the wife of Artabanes bothered to come to Constantinople in order to claim her marital rights in advance of the elapse of a similar deadline, see above). ${ }^{154}$ The continuous validity of these canons once more documents the significance of both forced and deliberate mobility in early medieval Armenian society, but also the possible dissolving effects of mobility on social ties established in the society of origin.

\section{5}

\section{Conclusion}

The various types of "Armenian" mobility we encounter in our sources hint at different frameworks of "networks" and "infrastructures", which permitted, but also somehow channelled mobility. The mobility of aristocrats took place within networks of allegiance, kinship and ethnic affiliation, which had been established between Armenia and the courts and administrative as well as military elites of the neighbouring great powers. The (both structural and imaginary) connections between ecclesiastical institutions, monasteries and places of veneration and education are reflected in the mobility of clergymen, pilgrims and scholars. Networks of commerce were based on the routes between places of production and markets, but also on relations of exchange and trust. The re-location of thousands of soldiers or the resettlement of ten thousands of refugees or deportees finally made highest demands on state infrastructures of transport, supply and distribution, then also of administrative control and taxation. These various networks were entangled; aristocrats or clergymen travelled along mercantile routes or on commercial ships, private and public transport of commodities and individuals were closely connected; ${ }^{155}$ Armenian mobility at large was often one effect of the traditional connections of allegiance within a society dominated by the aristocracy - when retainers followed their lord into the armed services of an empire or fled with him across the border.

We also observe not only a "multiplexity" of networks, but also of combinations of elements of "Armenian" identity (intertwined between self-definitions and attributions by others) with regard to language (the bilingual seal of Machitarios and Philippos), naming (the twins Baanes and Stephanos of

\footnotetext{
154 Mxit'ar Goš, Dastanagirk', transl. Thomson, pp. 132 (ch. 8), 136-137 (ch. 14) and 249-250 (ch. 206), with references for the older canons. See also Mardirossian, Le livre des canons.

155 On trade networks, cf. also Manandian, The Trade and Cities of Armenia.
} 


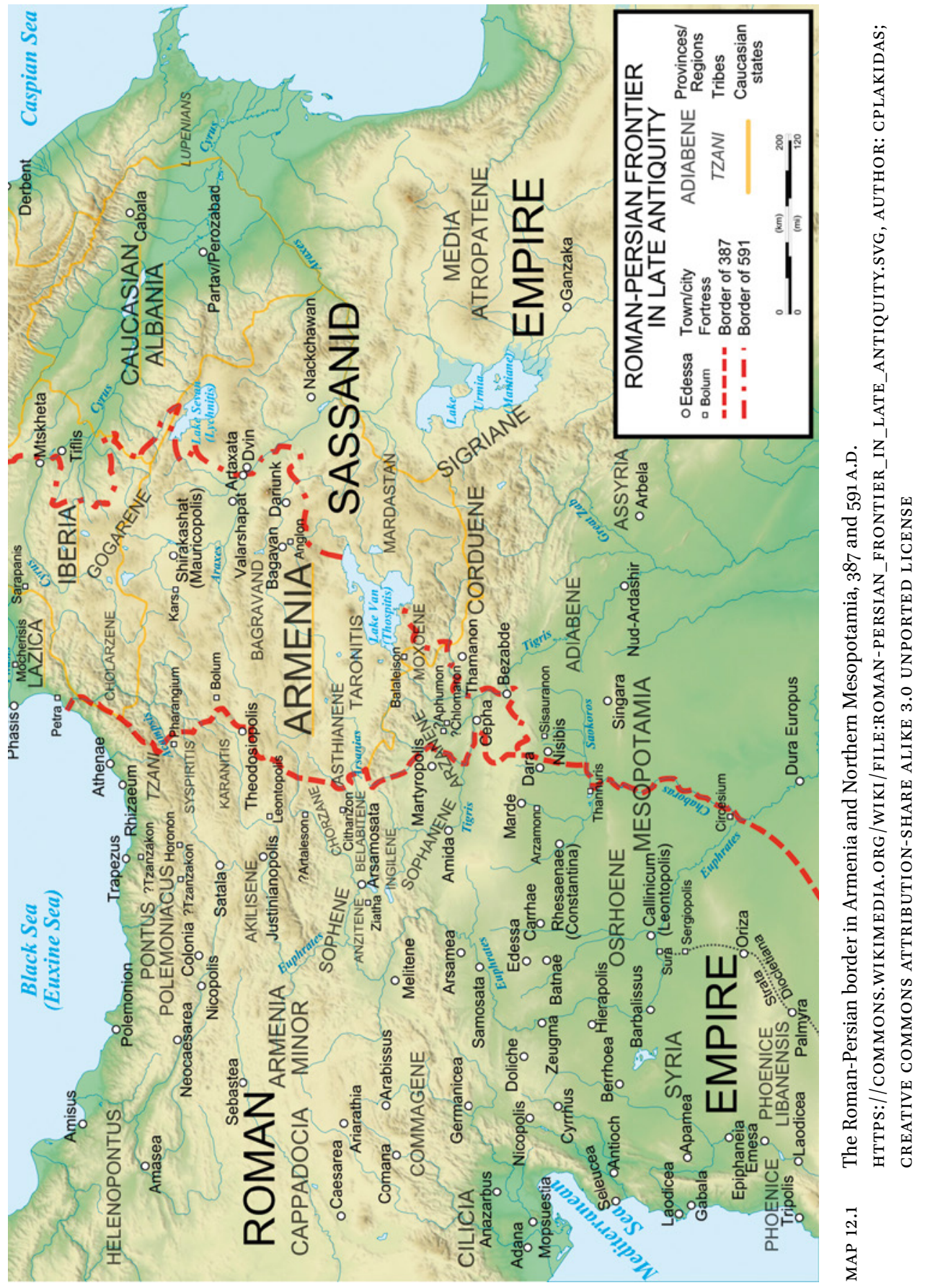




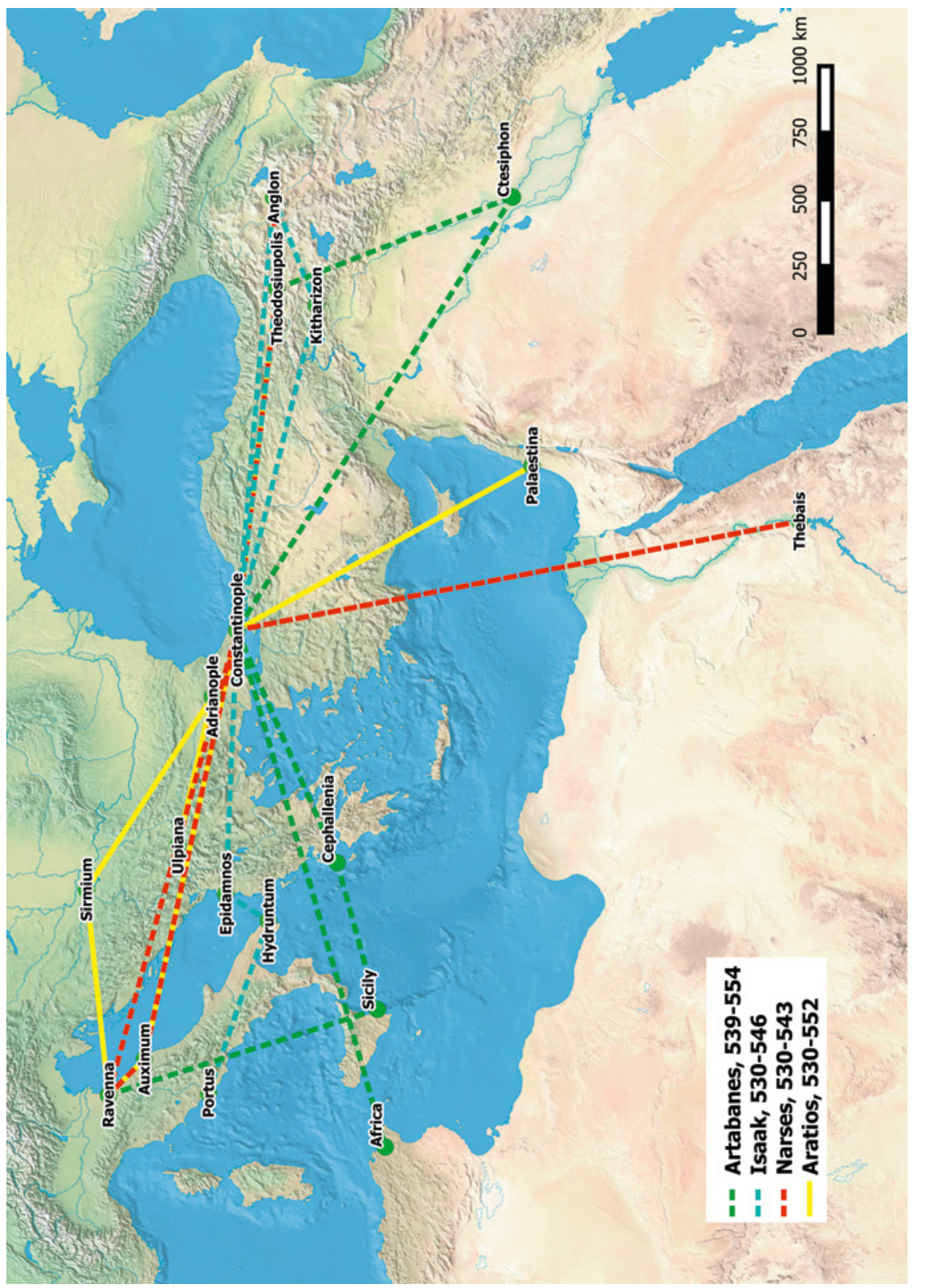

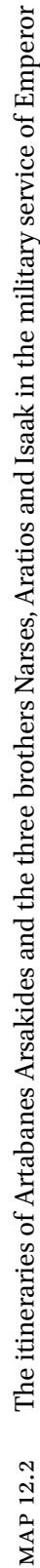



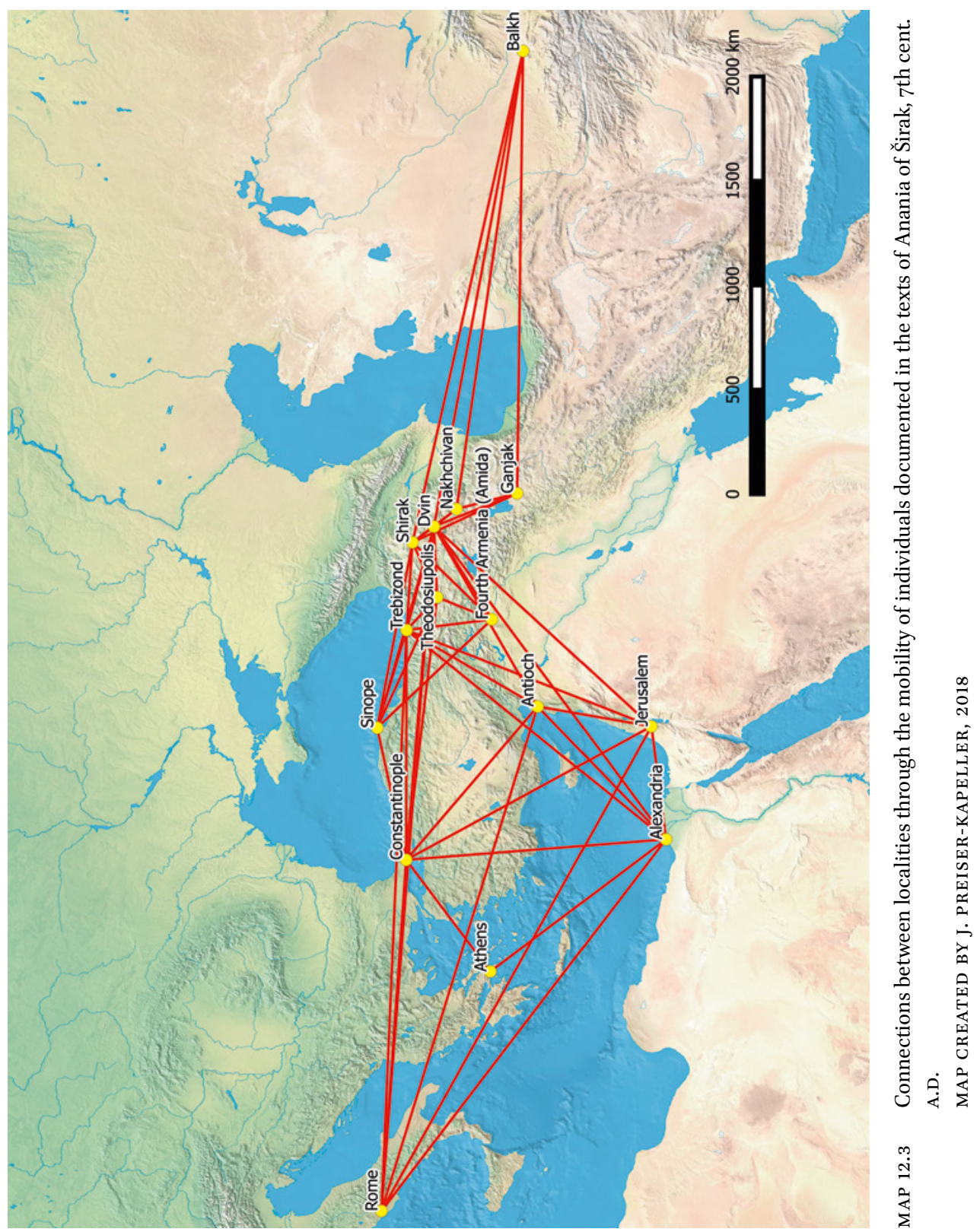


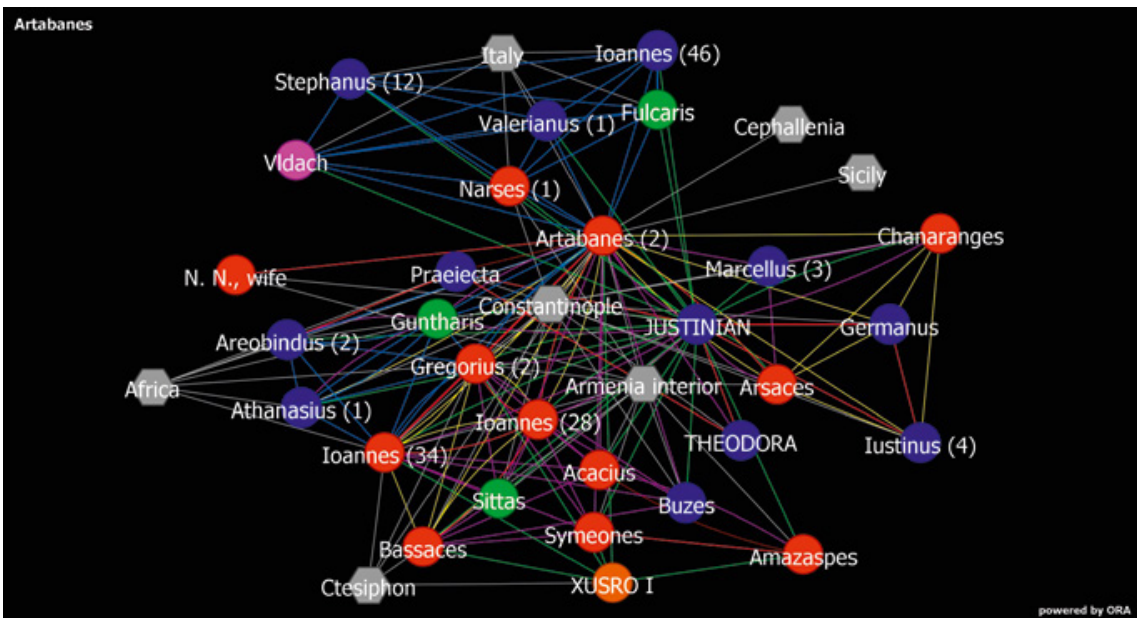

FIGURE 12.1 The social networks of Artabanes Arsakides as documented in Procopius (red nodes: Armenians, blue nodes: Roman, green nodes: Germanic origin, orange: Persians, grey nodes: localities; red links: kinship, green links: allegiance and patronage, blue links: joint military service, purple links: conflicts, yellow links: conspiracies, grey links: temporary presence at locality) GRAPH CREATED BY J. PREISER-KAPELLER, 2018

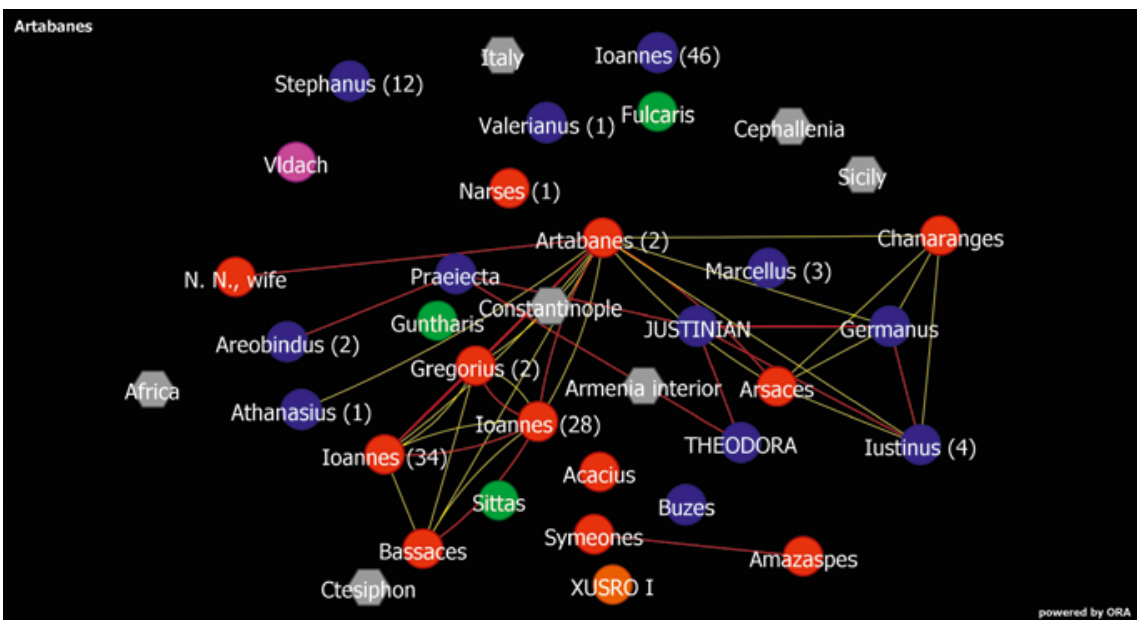

FIGURE 12.2 The social networks of Artabanes Arsakides as documented in Procopius (red nodes: Armenians, blue nodes: Roman, green nodes: Germanic origin, orange: Persians, grey nodes: localities; red links: kinship, yellow links: conspiracies) GRAPH CREATED BY J. PREISER-KAPELLER, 2018 


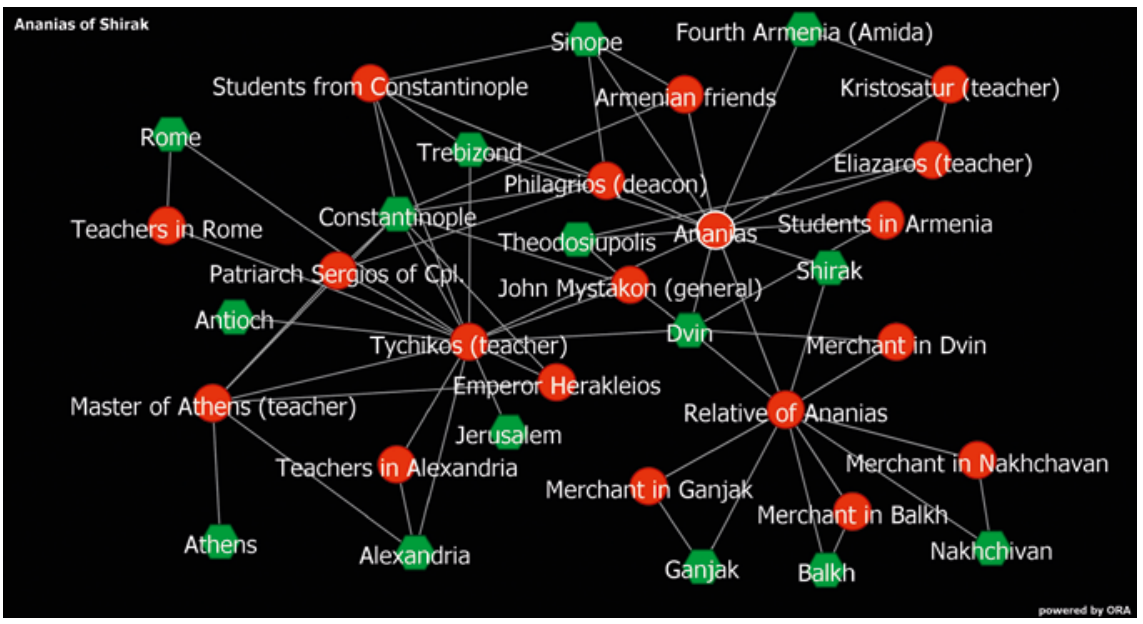

FIGURE 12.3 The connections between individuals (red) and localities (green) as documented in the biographical narratives of Ananias of Širak, 7 th cent.

GRAPH CREATED BY J. PREISER-KAPELLER, 2018

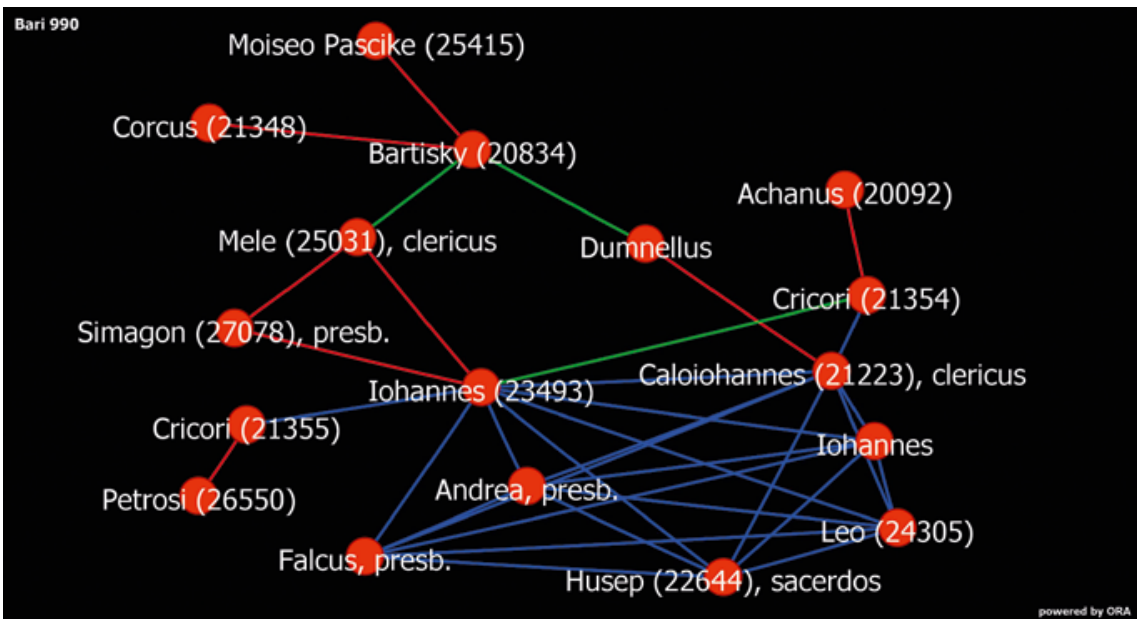

FIGURE 12.4 The social network emerging from a charter in Bari (Southern Italy), 990 (red links: kinship, green links: commercial interaction, blue links: juridical interaction)

GRAPH CREATED BY J. PREISER-KAPELLER, 2018

St. Mary of Bizye) or religion (non-Chalcedonian monks ejected from the "Roman Empire" founding a monastery called of "the Romans" in the realm of the Bagratuni), highlighting the inextricableness of spatial and cultural mobility. ${ }^{156}$

156 Cf. Greenblatt, Cultural Mobility. 
"Armenian mobility" was equally both a chance and a challenge for the neighbouring great powers, who tried to attract, but also to control Armenian mobility, to profit from, but also to limit the strength of ties of allegiance and ethnic affiliation, who wished for individuals with bilingual skills, but also of unquestionable loyalty (and, in the case of Byzantium, religious conformity). Several "microhistories" also uncover the tension between "Armenian-ness" attributed by contemporary sources (also in pejorative intention) or modern scholarship (maybe only on the basis of a "typical" Armenian name) and the actual relevance of such attributions for the identity and personal agency of an individual. ${ }^{157}$ The Armenian case thus provides especially rich material for a migration history of the medieval Afro-Eurasian transition zone.

\section{Bibliography}

\section{Primary Sources}

Actes de Lavra, ed. P. Lemerle/A. Guillou/N. Svoronos, Actes de Lavra, Première partie: des origines a 1204 (Archives de l'Athos 5), Paris 1970.

Agathangelos, History of the Armenians, ed. and transl. R.W. Thomson, Albany 1976.

Al-Baladhuri, transl. P.K. Hitti, The Origins of the Islamic State. Being a Translation of Kitâb Futûh al-Buldân of Abu-l Abbas Ahmad ibn Jabir al-Baladhuri, Reprint Piscataway, New Jersey 2002.

Ammianus Marcellinus, ed. W. Seyfarth, Ammiani Marcellini Rerum gestarum libri qui supersunt, Leipzig 1978.

Armenian Geography, transl. R.H. Hewsen, The Geography of Ananias of Širak

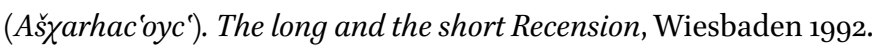

Buzandaran Patmut'iwnk', ed. P'awstosi Buzandac'woy Patmut'iwn Hayoc' $i$ čors dprut'iwns, Venice 1933.

Buzandaran Patmut'iwnk', transl. N.G. Garsoïan, The Epic Histories attributed to P'awstos Buzand (Buzandaran Patmut'iwnk'), Cambridge, Mass. 1989.

Chronicon ad annum Christi 1234, ed. J.-B. Chabot, Anonymi auctoris chronicon ad annum Christi 1234 pertinens (Corpus Scriptorum Christianorum Orientalium 109), Louvain 1937.

Chronicon ad annum Christi 1234, transl. The Seventh Century in the West-Syrian Chronicles, introd., transl. and annotated by A. Palmer. Including two seventh-century

157 The "Armenian" identity of Patriarch Photios beyond its usage in a diplomatic letter being one prominent case example, see above. For another case of the gth century, cf. also Preiser-Kapeller, "'Alī ibn Yahyāà al-Arman̄̄". 
Syriac Apocalyptic Texts, introd., transl. and annotated by S. Brock with added Annotation and an historical Introduction by R. Hoyland, Liverpool 1993, pp. 53-70.

Codice diplomatico barese IV, ed. F. Nitti Di Vito, Codice diplomatico barese: Vol. IV: Pergamene di S. Nicola di Bari, Bari 1900.

Concilium Quinisextum, ed. and transl. H. Ohme, Concilium Quinisextum. Das Konzil Quinisextum. Griechisch - Deutsch, Turnhout 2006.

Constantine Porphyrogenitus, De administrando imperii, ed. G. Moravcsik, transl. R.J.H. Jenkins (Corpus Fontium Historiae Byzantinae 1). Washington, D.C. 1967 (Reprint Washington, D.C. 1985).

Constantine Porphyrogenitus, De administrando imperii, transl. K. Belke/P. Soustal, Die Byzantiner und ihre Nachbarn. Die De administrando imperio genannte Lehrschrift des Kaisers Konstantinos Porphyrogennetos für seinen Sohn Romanos (Byzantinische Geschichtsschreiber 19), Vienna 1995.

Constantine Porphyrogenitus, De cerimoniis, ed. J.J. Reiske, Constantini Porphyrogeniti imperatoris de cerimoniis aulae byzantinae libri duo, Bonn 1829.

Ełišē, ed. E. Tēr-Minasean, Etišēi vasn Vardananc'ew Hayoc'Paterazmin, Erevan 1957.

Ełišē, transl. R.W. Thomson, Elishē, History of Vardan and the Armenian War, Cambridge, Mass./London 1982.

Łazar P'arpec'i, ed. G. Tēr Mkrtčcean/S. Mal’aseanc', Eazaray P'arpec'woy Patmut'iwn Hayoc'ew t'utt' ar Vahan Mamikonean, Tbilisi 1904.

Łazar P'arpec'i, transl. R.W. Thomson, The History of Lazar P'arpet'si, Atlanta 1991.

Łewond, ed. K. Ezean, Patmut'iwn Łewondeay Meci Vardapeti Hayoc', St. Petersburg 1887.

Łewond, transl. Z. Arzoumanian, History of Lewond, the Eminent Vardapet of the Armenians, Philadelphia 1982.

Malalas, John, ed. J. Thurn, Ioannis Malalae Chronographia (Corpus Fontium Historiae Byzantinae 35), Berlin/New York 2000.

Maurice, Strategicon, ed. G.T. Dennis, Das Strategikon des Maurikios, transl. E. Gamillscheg (Corpus Fontium Historiae Byzantinae 17), Vienna 1981.

Menander Protector, ed. and transl. R.C. Blockley, The History of Menander the Guardsman, Liverpool 1985 .

Michael the Syrian, ed. and transl. J.-B. Chabot, Chronique de Michel le Syrien, Patriarche Jacobite d'Antioche (1166-1199), 4 Vols., Paris 1899-1910 (Reprint Brussels 1963).

Movsēs Kałankatuac'i, ed. V. Arak'elyan, Movsēs Kałankatuac'i, Patmut'iwn Atowanic' ašxarhi, Erewan 1983.

Movsēs Kałankatuac'i, transl. C.F.J. Dowsett, The History of the Caucasian Albanians by Movsēs Dasxurançi (London Oriental Series, Vol. 8), London 1961.

Movsēs Xorenac'i, ed. M. Abełean/S. Yarut'iwnean, Movsēs Xorenac'i, Patmut'iwn Hayoc', Tbilisi 1913.

Movsēs Xorenac'i, transl. R.W. Thomson, Moses Khorenats'i, History of the Armenians, Cambridge, Mass./London 1978. 
Mxit'ar Goš, Dastanagirk', transl. R.W. Thomson, The Lawcode [Datastanagirk'] of Mxit'ar Goš, Amsterdam/Atlanta 2000.

Narratio de rebus Armeniae, ed. G. Garitte, La Narratio de rebus Armeniae (Corpus Scriptorum Christianorum Orientalium 132, Subsidia 4), Louvain $195^{2}$.

Narrationes de patribus Sinaïtis, ed. F. Nau, "Le texte grec des récits du moine Anastase sur les saints pères du Sinaï”, Oriens Christianus 2 (1902), 58-87.

Procopius, Bella, ed. and transl. H.B. Dewing, Procopius, History of the Wars, reprint Cambridge, Mass./London 1961.

Procopius, De aedificiis, ed. and transl. H.B. Dewing, Procopius, Buildings, reprint Cambridge, Mass./London 1961.

Sebēos, ed. G.V. Abgaryan, Patmut'iwn Sebēosi, Erevan 1979.

Sebēos, transl. R.W. Thomson/J. Howard-Johnston, The Armenian History attributed to Sebeos, 2 Vols., Liverpool 1999.

Stephen of Taron, ed. S. Mal $\chi$ asean, Step'anos Taronec'woy Patmut'iwn tiezerakan, St. Petersburg 1885 .

Stephen of Taron, transl. T. Greenwood, The Universal History of Step'anos Tarōnec'i. Introduction, Translation, and Commentary, Oxford 2017.

Tacitus, Annales, ed. Erich Koestermann, P. Cornelii Taciti libri qui supersunt. Tom. 1, Fasc. 1: Libri ab excessu Divi Augusti I-VI, Leipzig 1965.

Theodoros Stoudites, Letters, ed. G. Fatouros, Theodori Studitae Epistolae (Corpus Fontium Historiae Byzantinae 31/1-2), Berlin/New York 1992.

Theophanes, ed. C. de Boor, Theophanis chronographia, 2 vols., Leipzig 1883/1885.

Theophanes Continuatus, ed. I. Ševčenko, Chronographiae quae Theophanis Continuati nomine fertur Liber quo Vita Basilii imperatoris amplectitur (Corpus Fontium Historiae Byzantinae 42), Berlin 2011.

Theophylact Simocatta, ed. C. de Boor/P. Wirth, Theophylacti Simocattae Historiae, Stuttgart 1972.

Theophylact Simocatta, transl. P. Schreiner, Theophylaktos Simokattes, Geschichte (Bibliothek der Griechischen Literatur 20), Stuttgart 1985.

T'ovma Arcruni, Patmut'iwn, ed. K. Patkanean, T'ovmayi vardapeti Arcrownwoy Patmowt'iwn tann Arcrowneac', St. Petersburg 1887 (Reprint Tbilisi 1917).

T'ovma Arcruni, Patmut'iwn, transl. R.W. Thomson, Thomas Artsruni, History of the House of the Artsrunik', Detroit 1985.

Vardan Arewelc'i, ed. Ł. Ališan, Hawak'umn Patmut'iwn Hayoc', Venice 1862.

Vardan Arewelci, transl. R.W. Thomson, "The Historical Compilation of Vardan Arewelc 'i", Dumbarton Oaks Papers 43 (1989), 125-226.

Vita beati patris nostri Iohannis atque Euthymii, transl. P. Peeters, "Histoires monastiques géorgiennes, I. Vie des Ss. Jean et Euthyme”, AnBoll 36-37 (1917-1919), 8-68.

Yovhannēs Drasxanakertc'i, ed. E.V. Zagareišvili, Ioannes Draschanacertensis Historia Armeniae (786-925 A. D.), Tbilisi 1965. 
Yovhannēs Drasxanakertc'i, transl. K.H. Maksoudian, Yovhannēs Drasxanakertc'i, History of Armenia, Atlanta 1987.

\section{Secondary Literature}

Adontz, N., Armenia in the Period of Justinian. The political Conditions based on the Naxarar System, translated with partial Revisions, a bibliographical Note and Appendices by N.G. Garsoïan, Lisbon 1970.

Asa Eger, A., The Islamic-Byzantine Frontier. Interaction and Exchange among Muslim and Christian Communities, London/New York 2015.

Aslanian, S.D., From the Indian Ocean to the Mediterranean: The Global Trade Networks of Armenian Merchants from New Julfa, Berkeley/London/New York 2011.

Austin, N.J.E./Rankov, N.B., Exploratio: Military and Political Intelligence in the Roman World from the Second Punic War to the Battle of Adrianople, New York 1995.

Ayvazyan, A., The Armenian Military in the Byzantine Empire. Conflict and Alliance under Justinian and Maurice, Alfortville 2012.

Beihammer, A.D., Nachrichten zum byzantinischen Urkundenwesen in arabischen Quellen (565 bis 811) (Poikila byzantina 17), Bonn 2000.

Blockley, R.C. "The Division of Armenia between the Romans and the Persians at the End of the 4th Century", Historia 36 (1987), 222-234.

Börm, H., Prokop und die Perser. Untersuchungen zu den römisch-sasanidischen Kontakten in der ausgehenden Spätantike, Stuttgart 2007.

Brousselle, I., "L'integration des Arméniens dans l'aristocratie byzantine aux Ixe siècle", in L'Arménie et Byzance. Histoire et culture (Byzantine Sorbonensia 12), Paris 1996, pp. 43-54.

Charanis, P., "The Armenians in the Byzantine Empire", Byzantinoslavica 22 (1961), 196-240.

Brousselle, I., "The Transfers of Population as a Policy in the Byzantine Empire", Comparative Studies in Society and History 3/2 (1961), 140-154.

Chaumont, M.-L., "L'Arménie entre Rome et l'Iran. I. De l'avènement d'Auguste à l'avènement de Dioclétien", in H. Temporini (ed.), Aufstieg und Niedergang der Römischen Welt. Geschichte und Kultur Roms im Spiegel der neueren Forschung II. Prinzipat IX (1. Halbband), Berlin/New York 1976, pp. 71-194.

Cheynet, J.C., Pouvoir et contestations à Byzance (963-1210), Paris 1990.

Cheynet, J.C., "Les Arméniens de l'empire en Orient de Constantin X à Alexis Comnène (1059-1081)", in L'Arménie et Byzance. Histoire et culture (Byzantine Sorbonensia 12), Paris 1996, pp. $67-78$.

Christensen, A., L'Iran sous les Sassanides, Copenhagen 1944.

Clackson, J., "A Greek Papyrus in Armenian Script", Zeitschrift für Papyrologie und Epigraphik 129 (2000), 223-258. 
Clackson, J., "New Readings on the Armeno-Greek Papyrus BnF 332 Arm”, Zeitschrift für Papyrologie und Epigraphik 141 (2002), 116.

Coulie, B./Nesbitt, J., "A Bilingual Rarity in the Dumbarton Oaks Collection of Lead Seals: A Greek/Armenian Bulla of the Later 1oth/Early 11th Centuries", Dumbarton Oaks Papers 43 (1989), 121-123.

Dadoyan, S.B., The Fatimid Armenians. Cultural and Political Interaction in the Near East, Leiden 1997.

Dadoyan, S.B., The Armenians in the Medieval Islamic World: Paradigms of Interaction, Seventh to Fourteenth Centuries, Vol. I: The Arab Period in Arminyah. Seventh to Eleventh Centuries, New Brunswick/London 2011.

Dadoyan, S.B., The Armenians in the Medieval Islamic World: Paradigms of Interaction, Seventh to Fourteenth Centuries, Vol. II:Armenian Realpolitik in the Islamic World and Diverging Paradigms. Case of Cilicia Eleventh to Fourteenth Centuries, New Brunswick/London 2013.

Dédéyan, G., "Mleh le Grand, stratège de Lykandos", Revue des Études Arméniennes, N.S. 15 (1981), 73-102.

Dédéyan, G., "Le rôle des Arméniens en Syrie du Nord pendant la reconquête byzantine (vers 945-1031)", Byzantinische Forschungen 25 (1999), 249-284.

Dédéyan, G., "Reconquête territorial et immigration arménienne dans l'aire cilicienne sous les empereurs macédoniens (de 867 à 1028)"; in: M. Balard/A. Ducellier (eds.), Migrations et diasporas méditerranéennes (Xe-XVIe siècles), Paris 2002, pp. 11-32.

Dédéyan, G., Les Arméniens entre Grecs, Musulmans et Croisés: étude sur les pouvoirs arméniens dans le Proche-Orient méditerranéen (1068-1150), 2 vols., Lisbon 2003.

Dédéyan, G., "Le stratège Symbatikios et la colonisation Arménienne dans la thème de Longobardie", in: Ravenna da capitale imperiale a capitale esarcale. Atti del XVII Congresso internazionale di studio sull'alto medioevo, Ravenna, 6-12 giugno 2004, Spoleto 2005, vol. I, pp. 461-493.

Dédéyan, G. (ed.), Histoire du peuple arméniens, Toulouse 2007.

Dignas, B./Winter, E., Rome and Persia in Late Antiquity. Neighbours and Rivals, Cambridge 2007 .

Ditten, H., Ethnische Verschiebungen zwischen der Balkanhalbinsel und Kleinasien vom Ende des 6. bis zur zweiten Hälfte des 9. Jahrhunderts (Berliner Byzantinische Arbeiten 59), Berlin 1993.

Dölger, F., Regesten der Kaiserurkunden des oströmischen Reiches von 565-1453. 1. Teil, 2. Halbband: Regesten von 867-1025, Zweite Auflage neu bearbeitet von A.E. Müller, unter verantwortlicher Mitarbeit von A. Beihammer, Munich 2003.

Dölger, F., Regesten der Kaiserurkunden des oströmischen Reiches von 565-1453. 1. Teil, ı. Halbband: Regesten von 565-867, Zweite Auflage neu bearbeitet von A.E. Müller/J. Preiser-Kapeller/A. Riehle, Munich 2009. 
Dorfmann-Lazarev, I., Arméniens et Byzantins à l'époque de Photius: deux débats théologiques après le triomphe de l'orthodoxie (Corpus Scriptorum Christianorum Orientalium 609, Subsidia 117), Louvain 2004.

Elias, N., Die höfische Gesellschaft. Untersuchungen zur Soziologie des Königtums und der höfischen Aristokratie, Frankfurt am Main 1969.

Faroqhi, S., The Ottoman Empire and the World around it, New York 2004.

Felix, W., Byzanz und die islamische Welt im früheren 11. Jahrhundert (Byzantina Vindobonensia 14), Vienna 1981.

Garsoïan, N.G., The Paulician Heresy. The study of the origin and development of Paulicianism in Armenia and the eastern provinces of the Byzantine Empire, Mouton/Den Haag 1967 .

Garsoïan, N.G., "Armenia in the fourth Century. An Attempt to Re-Define the Concepts 'Armenia' and 'Loyalty”, Revue des Études Arméniennes NS 8 (1971), 341-352.

Garsoïan, N.G., "The Arab Invasion and the Rise of the Bagratuni", in R.G. Hovannisian (ed.), The Armenian People from ancient to modern Times, Vol. I., The Dynastic Periods: From Antiquity to the Fourteenth Century, New York 1997, pp. 117-142.

Garsoïan, N.G., "The Aršakuni Dynasty (A.D. 12-[180?]-428)", in R.G. Hovannisian (ed.), The Armenian People from ancient to modern Times, Vol. I.: The Dynastic Periods: From Antiquity to the Fourteenth Century, New York 1997, pp. 63-94.

Garsoïan, N.G., "The Byzantine Annexiation of the Armenian Kingdoms in the Eleventh Century", in R.G. Hovannisian (ed.), The Armenian People from ancient to modern Times, Vol. I., The Dynastic Periods: From Antiquity to the Fourteenth Century, New York 1997, pp. 187-198.

Garsoïan, N.G., "The Independent Kingdoms of Medieval Armenia", in R.G. Hovannisian (ed.), The Armenian People from ancient to modern Times, Vol. I.: The Dynastic Periods: From Antiquity to the Fourteenth Century, New York 1997, pp. 143-185.

Garsoïan, N.G., "The Marzpanate (428-652)", in R.G. Hovannisian (ed.), The Armenian People from ancient to modern Times, Vol. I., The Dynastic Periods: From Antiquity to the Fourteenth Century, New York 1997, pp. 95-115.

Garsoïan, N.G., "The Problem of Armenian Integration into the Byzantine Empire", in H. Ahrweiler/A.E. Laiou (ed.), Studies on the Internal Diaspora of the Byzantine Empire, Washington, D.C. 1998, pp. 53-124.

Garsoïan, N.G., L'église arménienne et le grand schisme d'Orient (Corpus Scriptorum Christianorum Orientalium 574, Subsidia 100), Louvain 1999.

Garsoïan, N.G., "Armenien”, in L. Pietri (ed.), Der Lateinische Westen und der Byzantinische Osten (431-642) (Die Geschichte des Christentums 3), Freiburg/Basel/Vienna 2001, pp. 1187-1230.

Garsoïan, N.G., Interregnum. Introduction to a Study on the Formation of Armenian Identity (ca 6oo-75o) (Corpus Scriptorum Christianorum Orientalium 640, Subsidia 127), Louvain 2012. 
Goubert, P., Byzance avant l'Islam I: Byzance et l'orient sous les successeurs de Justinien. L'empereur Maurice, Paris 1951.

Greatrex, G., "The Background and Aftermath of the Partition of Armenia in AD 387 ", The Ancient History Bulletin 14, 1-2 (2000), 35-48.

Greatrex, G./Lieu, S.N.C., The Roman Eastern Frontier and the Persian Wars. Part II: A.D. 363-63o. A narrative Sourcebook, London/New York 2002.

Greenblatt, St., Cultural Mobility: A Manifesto, Cambridge 2009.

Greenwood, T.W., "Sasanian Echoes and Apocalyptic Expectations: A Re-Evaluation of the Armenian History attributed to Sebeos", Le Muséon 115, Fasc. 1-2 (2002), 323-397.

Greenwood, T.W., "A Corpus of Early Medieval Armenian Inscriptions", Dumbarton Oaks Papers 58 (2004), 27-91.

Greenwood, T.W., "Failure of a Mission? Photius and the Armenian Church", Le Muséon 119, Fasc. 1-2 (2006), 123-167.

Greenwood, T.W., "Armenian Neighbours (600-1045)", in J. Shepard (ed.), The Cambridge History of the Byzantine Empire c. 500-1492, Cambridge 2008, pp. 333-364.

Greenwood, T.W., "A Reassessment of the Life and mathematical Problems of Anania Širakac'i”, Revue des Études Arméniennes N.S. 33 (2011), 131-186.

Grousset, R., Histoire de l'Arménie des origines à 107ı, Paris 1947 (New edition 1984).

Güterbock, K., "Römisch-Armenien und die römischen Satrapien im vierten bis sechsten Jahrhundert", in Festgabe der juristischen Fakultät zu Königsberg für ihren Senior Johann Theodor Schirmer zum 1. August 19oo, Königsberg 1900, pp. 1-58.

Güterbock, K., Byzanz und Persien in ihren diplomatisch-völkerrechtlichen Beziehungen im Zeitalter Justinians. Ein Beitrag zur Geschichte des Völkerrechts, Berlin 1906.

Gylfi Magnússon, S./Szijárto, I.M., What is Microhistory? Theory and Practice, London/ New York 2013.

Hahn, S., Historische Migrationsforschung, Frankfurt/New York 2012.

Haldon, J.F., "The Fate of the Late Roman Senatorial Elite: Extinction or Transformation", in J. Haldon/L.I. Conrad (eds.), The Byzantine and Early Islamic Near East: Elites Old and New, Princeton 2004, pp. 179-234.

Haldon/L.I. Conrad/Kennedy, H., "The Arab-Byzantine Frontier in the Eighth and Ninth Centuries. Military Organisation and Society in the Borderlands", Zbornik radova Vizantološkog instituta 19 (1980), 79-116.

Halsall, G., Barbarian Migrations and the Roman West, Cambridge 2007.

Harzig, C./Hoerder, D., with D. Gabaccia, What is Migration History?, Malden, MA 2009 .

Hewsen, R.H., "Science in Seventh-Century Armenia: Ananias of Sirak”, Isis 59/1 (1968), $32-45$.

Hewsen, R.H., Armenia: A Historical Atlas, Chicago 2001.

Hoerder, D., Cultures in Contact. World Migrations in the Second Millennium, Durham/ London 2002. 
Honigmann, E., Die Ostgrenze des byzantinischen Reiches von 363 bis 1071 nach griechischen, arabischen, syrischen und armenischen Quellen, Brussels 1953.

Hovannisian, R.G. (ed.), Armenian Van/Vaspurakan, Costa Mesa, CA 2000.

Hovannisian, R.G./Payaslian, S. (eds.), Armenian Constantinople, Costa Mesa, CA 2010.

Isaac, B., "The Army in the Late Roman East: the Persian Wars and the Defence of the Byzantine Provinces", in A. Cameron (ed.), The Byzantine and Early Islamic Near East III: States, Resources and Armies, Princeton 1995, pp. 125-155.

Jones, L., Between Islam and Byzantium: Aght'amar and the Visual Construction of Medieval Armenian Rulership, Farnham 2007.

Kafadar, C., Between Two Worlds. The Construction of the Ottoman State, Berkeley/Los Angeles/London 1996.

Kaldellis, A., Romanland. Ethnicity and Empire in Byzantium, Cambridge, Mass./London 2019 .

Kazhdan, A./Ronchey, S., L'aristocrazia bizantina dal principio dell'XI alla fine del XII secolo, Palermo 1999.

Kelly, Chr., Ruling the Later Roman Empire (Revealing Antiquity 15), Cambridge, Mass./ London 2006.

Kosto, A.J., Hostages in the Middle Ages, Oxford 2012.

Laiou, A., "The Life of St. Mary the Younger", in: A.-M. Talbot (ed.), Holy Women of Byzantium: Ten Saints' Lives in English Translation, Washington, D.C. 1996, pp. 239-289.

L'Arménie et Byzance. Histoire et culture (Byzantine Sorbonensia 12), Paris 1996.

Laurent, J., L'Arménie entre Byzance et l'Islam depuis la conquête arabe jusqu'en 886, Nouvelle édition revue et mise à jour par M. Canard, Lisbon 1980.

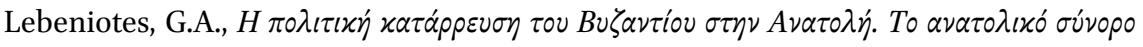

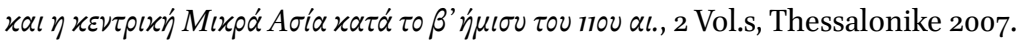

Lee, A.D., Information and Frontiers. Roman Foreign Relations in Late Antiquity, Cambridge 1993 .

Lilie, R.-J., "Sonderbare Heilige. Zur Präsenz orthodoxer Heiliger im Westen während des 11. Jahrhunderts", Millenium 5 (2008), 225-259.

Lounghis, T.C./Blysidu, B./Lampakes, St., Regesten der Kaiserurkunden des Oströmischen Reiches von 476 bis 565 (Quellen und Studien zur Geschichte Zyperns 52), Nicosia 2005 .

Ludwig, C., "Wer hat was in welcher Absicht wie geschrieben? Bemerkungen zur Historika des Petros Sikeliotes über die Paulikianer", in Varia II (Poikila Byzantina 6), Bonn 1987, pp. 149-227.

Magdalino, P., "Court Society and Aristocracy", in J. Haldon (ed.), A Social History of Byzantium, Maldon/Oxford/Chichester 2009, pp. 212-232. 
Mahé, J.-P., "Die armenische Kirche von 611 bis 1066”, in G. Dagron/P. Riché/A. Vauchez (eds.), Bischöfe, Mönche und Kaiser (642-1054) (Die Geschichte des Christentums 4), Freiburg/Basel/Vienna 1994, pp. 473-542.

Manandian, H.A., The Trade and Cities of Armenia in Relation to Ancient World Trade, Lisbon 1965.

Mardirossian, A., Le livre des canons arméniens (Kanonagirk' Hayoc') de Yovhannēs Awjnec i. Église, droit et société en Arménie du $\mathrm{IV}^{e}$ au VIII ${ }^{e}$ siècle (Corpus Scriptorum Christianorum Orientalium 6o6, Subsidia 116), Louvain 2004.

Martin-Hisard, B., "L'Athos, l'Orient et le Caucase au XIe siècle", in: A. Bryer/ M. Cunningham (eds.), Mount Athos and Byzantine Monasticism, Aldershot 1996, pp. 239-248.

Martin-Hisard, B., "Constantinople et les archontes caucasiens dans le Livre de cérémonies, II, 48", Travaux et Mémoires 13 (2000), 359-530.

McCormick, M., “The Imperial Edge: Italo-Byzantine Identity, Movement and Integration, A.D. 650-950", in H. Ahrweiler/A.E. Laiou (eds.), Studies on the Internal Diaspora of the Byzantine Empire, Washington, D.C. 1998, pp. 17-52.

McCormick, M., Charlemagne's Survey of the Holy Land: Wealth, Personnel, and Buildings of a Mediterranean Church between Antiquity and the Middle Ages, Washington, D.C. 2011.

McGeer, E., The Land Legislation of the Macedonian Emperors. Translation and Commentary (Medieval Sources in Translation 38), Toronto 2000.

Meier, M., Das andere Zeitalter Justinians. Kontingenzerfahrung und Kontingenzbewältigung im 6. Jahrhundert n. Chr. (Hypomnemata. Untersuchungen zur Antike und zu ihrem Nachleben 147), Göttingen 2003.

Mutafian, Cl., "L'immigration arménienne en Italie", in: M. Balard/A. Ducellier (eds.), Migrations et diasporas méditerranéennes (Xe-XVIe siècles), Paris 2002, pp. 33-41.

Nichanian, M., "Byzantine Emperor Philippikos-Vardanes. Monothelite Policy and Caucasian Diplomacy", in R.G. Hovannisian/S. Payaslian (eds.), Armenian Constantinople, Costa Mesa, CA 2010, pp. 39-51.

Oikonomides, N., "Title and Income at the Byzantine Court", in H. Maguire (ed.), Byzantine Court Culture from 829 to 1204, Washington, D.C. 1997, pp. 199-215.

Pohl, W., "Staat und Herrschaft im Frühmittelalter: Überlegungen zum Forschungsstand", in St. Airlie/H. Reimitz/W. Pohl (eds.), Staat im Frühen Mittelalter (Forschungen zur Geschichte des Mittelalters 11), Vienna 2006, pp. 9-38.

Pourshariati, P., Decline and Fall of the Sasanian Empire: The Sasanian-Parthian Confederacy and the Arab Conquest of Iran, London/New York 2008.

Preiser-Kapeller, J., Die Verwaltungsgeschichte des byzantinischen Armenien vom 5. bis zum 7.Jahrhundert (Entstehung des Themas Armeniakon), Master-Thesis, University of Vienna 2001. 
Preiser-Kapeller, J., "Magister Militum per Armeniam (Ho ton Armeniakon Strategos). Überlegungen zum armenischen Kommando im 6. und 7. Jahrhundert", in W. Hörandner/J. Koder/M. Stassinopoulou (eds.), Wiener Byzantinistik und Neogräzistik (Byzantina et Neograeca Vindobonensia 24), Vienna 2004, pp. 348-365.

Preiser-Kapeller, J., "Hrovartak. Bemerkungen zu den kaiserlichen ,Bestallungsschreiben' für Adelige in der Kaukasusregion im 7.-9. Jahrhundert in armenischer Überlieferung", in Ch. Stavrakos/A.-K. Wassiliou/M.K. Krikorian (eds.), Hypermachos. Studien zu Byzantinistik, Armenologie und Georgistik. Festschrift für Werner Seibt zum 65. Geburtstag, Wiesbaden 2008, pp. 295-314.

Preiser-Kapeller, J., "Kaysr, tun und 'asabīyya. Der armenische Adel und das Byzantinische Reich im späten 6. Jh. in der Darstellung des Sebēos zugeschriebenen Geschichtswerks", in M. Popović/J. Preiser-Kapeller (eds.), Junge Römer - Neue Griechen. Eine byzantinische Melange aus Wien, Vienna 2008, pp. 187-202.

Preiser-Kapeller, J., "Between New Jerusalem and the Beast in Human Form. The Picture of the Later Roman and Early Byzantine State in the Armenian Historiography of the 5th to 8th century", Pro Georgia. Journal of Kartvelological Studies 19 (2009), $5^{1-95}$.

Preiser-Kapeller, J., "erdumn, ucht, carayut'iwn. Armenian aristocrats as diplomatic partners of Eastern Roman Emperors, 387-884/885 AD”, Armenian Review $5^{2}$ (2010), 139-215.

Preiser-Kapeller, J., "A Collapse of the Eastern Mediterranean? New results and theories on the interplay between climate and societies in Byzantium and the Near East, ca. 1000-1200 AD", Jahrbuch der Österreichischen Byzantinistik 65 (2015), 195-242.

Preiser-Kapeller, J., "Vom Bosporus zum Ararat. Die Wirkung und Wahrnehmung des Byzantinischen Reiches in Armenien”, in: F. Daim/Ch. Gastgeber (eds.), Byzantium as Bridge between West and East, Vienna 2015, pp. 179-215.

Preiser-Kapeller, J., "Complex processes of migration: the south Caucasus in the early Islamic Empire (7th-10th century AD)", in H. Mehler et al. (eds.), Migration und Integration von der Urgeschichte bis zum Mittelalter, Halle 2017, pp. 295-313.

Preiser-Kapeller, J., "Central Peripheries. Empires and Elites across Byzantine and Arab Frontiers in Comparison (700-90o CE)", in W. Drews (ed.), Die Interaktion von Herrschern und Elitengruppen in imperialen Ordnungen des Mittelalters, Berlin/Boston 2018, pp. 91-112.

Preiser-Kapeller, J., “'Alī ibn Yahyā al-Armanī and the 'Armenian Connection' between Bosporus, Tigris and Nile in the mid-gth century CE", in E. Bonfiglio/C. Rapp (eds.), Armenia and Byzantium, forthcoming 2021.

Prosopographie der mittelbyzantinischen Zeit Online, Database De Gruyter, 2014: https://www.degruyter.com/view/db/pmbz.

The Prosopography of the later Roman Empire, I-III, ed. A.H. Martin Jones et al., Cambridge 1971-1992. 
Redgate, A.E., The Armenians (The Peoples of Europe), Oxford 1998.

Redgate, A.E., "Myth and Reality. Armenian Identity in the Early Middle Ages", National Identities 9:4 (2007), 281-306.

Rubin, Z., "Nobility, Monarchy and Legitimation under the Later Sasanians", in J. Haldon/L.I. Conrad (eds.), The Byzantine and Early Islamic Near East: Elites Old and New, Princeton 2004, pp. 235-273.

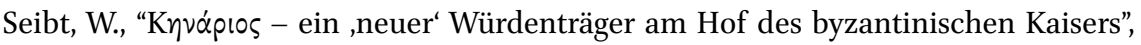
Handes Amsorya 88 (1974), 369-380.

Seibt, W., "Die Eingliederung von Vaspurakan in das Byzantinische Reich (etwa Anfang 1019 bzw. Anfang 1022)", Handes Amsorya 92 (1978), 49-66.

Seibt, W., "'Armenika themata” als terminus technicus der byzantinischen Verwaltungsgeschichte des 11. Jahrhundert", Byzantinoslavica 54 (1993), 134-141.

Seibt, W., "Der historische Hintergrund und die Chronologie der Christianisierung Armeniens bzw. der Taufe König Trdats (ca. 315)", in: id. (ed.), Die Christianisierung des Kaukasus. The Christianization of Caucasus (Armenia, Georgia, Albania). Referate des Internationalen Symposions (Wien, 9.-12. Dezember 1999), Vienna 2002, pp. $125^{-133 .}$

Seibt, W., "Stärken und Schwächen der byzantinischen Integrationspolitik gegenüber den neuen armenischen Staatsbürgern im 11. Jh.", in V.N. Vlyssidou (ed.), The Empire in Crisis (?): Byzantium in the 11th Century (1025-1081) (Institute for Byzantine Research, International Symposium, 11). Athens 2003, pp. 331-347.

Seibt, W./Preiser-Kapeller, J. (eds.), The Creation of the Caucasian Alphabets as Phenomenon of Cultural History (Veröffentlichungen zur Byzanzforschung 28), Vienna 2011.

Settipani, Ch., Continuité des élites à Byzance durant les siècles obscurs: les princes caucasiens et l'Empire de vie au IXe siècle, Paris 2007.

Shirinian, M.E., "Armenian Elites in Constantinople. Emperor Basil and Patriarch Photius", in: R.G. Hovannisian/S. Payaslian (eds.), Armenian Constantinople, Costa Mesa, CA 2010, pp. 53-72.

Stone, M., "The Greek Background of Some Sinai Armenian Pilgrims and Some Other Observations", in M. Stone/Th. Samuelian (eds.), Medieval Armenian Culture, Chico 1983, pp. 194-202.

Svoronos, N., Les novelles des empereurs Macédoniens concernant la terre et les stratiotes. Introduction, edition, commentaires. Édition posthume et index établis par P. Gounaridis, Athens 1994.

Tchekhanovets, Y., The Caucasian Archaeology of the Holy Land. Armenian, Georgian and Albanian communities between the fourth and eleventh centuries $C E$, Leiden 2018.

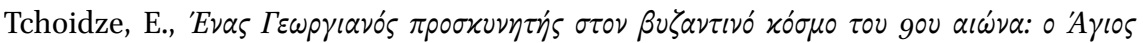

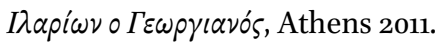


Ter-Ghewondyan, A., The Arab Emirates in Bagratid Armenia, transl. by N.G. Garsoïan, Lisbon 1976.

Terian, A., "The Hellenizing School. Its Time, Place, and Scope of Activities Reconsidered", in N.G. Garsoïan/Th.F. Mathews/R.W. Thomson (eds.), East of Byzantium: Syria and Armenia in the Formative Period, Washington, D.C. 1982, pp. 175-186.

Terian, A., "Xorenac'i and Eastern Historiography of the Hellenistic Period", Revue des Études Arméniennes N.S. 28 (2001-2002), 101-141.

Thomson, R.W., "Armenia (400-60o)", in J. Shepard (ed.), The Cambridge History of the Byzantine Empire c. 500-1492, Cambridge 2008, pp. 156-172.

Thomson, R.W., "Constantinople in Early Armenian Literature”, in: R.G. Hovannisian/S. Payaslian (eds.), Armenian Constantinople, Costa Mesa, CA 2010, pp. 20-34.

Todt, K.-P./Vest, B.A., Syria (Syria Prōtē, Syria Deuteria, Syria Euphratēsia) (Tabula Imperii Byzantini 15), Vienna 2014.

Toumanoff, C., Studies in Christian Caucasian History, Washington, D.C. 1963.

Toumanoff, C., "Caucasia and Byzantium”, Traditio 27 (1971), 111-158.

Treadgold, W., The Early Byzantine Historians, Basingstoke 2006.

Treitinger, O., Die oströmische Kaiser- und Reichsidee nach ihrer Gestaltung im höfischen Zeremoniell, Darmstadt 1956.

Tritle, L.A., "Tatzates' Flight and the Byzantine-Arab Peace Treaty of 782", Byzantion 47 (1977), 279-300.

Turner, D., "The Origins and Accession of Leo v (813-820)",Jahrbuch der Österreichischen Byzantinistik 40 (1990), 171-203.

Vaux, B., Linguistic manifestations of Greek-Armenian contact in Late Antiquity and Byzantium. Working Paper (2009), online: http://www.academia.edu/181300/Linguistic _manifestations_of_Greek-Armenian_contact_in_Late_Antiquity_and_Byzantium _handout_see_powerpoint_file_above_for_images.

Weitenberg, J., "Linguistic continuity in Armenian Hellenizing texts", Le muséon 110 (1997), 447-458.

Whitby, M., "Recruitment in Roman Armies from Justinian to Heraclius (ca. 565-615)", in A. Cameron (ed.), The Byzantine and Early Islamic Near East III: States, Resources and Armies, Princeton 1995, pp. 61-124.

Whittow, M., The Making of Byzantium, 6oo-1025, Berkeley/Los Angeles 1996.

Wilkinson, J., Jerusalem Pilgrims before the Crusades, Warminster 2002.

Zekiyan, L.B., "Le Colonie Armene del medio evo in Italia e le relazioni cultural ItaloArmene", in: Atti del primo simposio internazionale di arte Armena (Bergamo, 28-30 giugna 1975), Venice 1978, pp. 803-929. 